Atmos. Chem. Phys., 17, 10565-10582, 2017

https://doi.org/10.5194/acp-17-10565-2017

(C) Author(s) 2017. This work is distributed under

the Creative Commons Attribution 3.0 License.

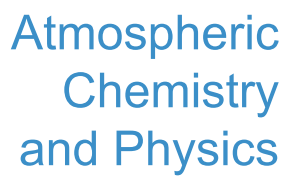

(c) (†)

\title{
Chemical processes related to net ozone tendencies in the free troposphere
}

\author{
Heiko Bozem ${ }^{1, \mathrm{a}}$, Tim M. Butler ${ }^{2}$, Mark G. Lawrence ${ }^{2}$, Hartwig Harder ${ }^{1}$, Monica Martinez ${ }^{1}$, Dagmar Kubistin ${ }^{1, \mathrm{~b}}$, \\ Jos Lelieveld $^{1}$, and Horst Fischer ${ }^{1}$ \\ ${ }^{1}$ Atmospheric Chemistry Department, Max Planck Institute for Chemistry, P.O. Box 3060, 55020 Mainz, Germany \\ ${ }^{2}$ Institute for Advanced Sustainability Studies e.V. Potsdam, Berliner Strasse 30, 14467 Potsdam, Germany \\ ${ }^{a}$ now at: Institute for Atmospheric Physics, Johannes Gutenberg University, Mainz, Germany \\ ${ }^{b}$ now at: DWD, Hohenpeißenberg, Germany \\ Correspondence to: Heiko Bozem (bozemh@uni-mainz.de)
}

Received: 17 February 2017 - Discussion started: 24 February 2017

Revised: 5 July 2017 - Accepted: 17 July 2017 - Published: 8 September 2017

\begin{abstract}
Ozone $\left(\mathrm{O}_{3}\right)$ is an important atmospheric oxidant, a greenhouse gas, and a hazard to human health and agriculture. Here we describe airborne in situ measurements and model simulations of $\mathrm{O}_{3}$ and its precursors during tropical and extratropical field campaigns over South America and Europe, respectively. Using the measurements, net ozone formation/destruction tendencies are calculated and compared to 3-D chemistry-transport model simulations. In general, observation-based net ozone tendencies are positive in the continental boundary layer and the upper troposphere at altitudes above $\sim 6 \mathrm{~km}$ in both environments. On the other hand, in the marine boundary layer and the middle troposphere, from the top of the boundary layer to about $6-8 \mathrm{~km}$ altitude, net $\mathrm{O}_{3}$ destruction prevails. The ozone tendencies are controlled by ambient concentrations of nitrogen oxides $\left(\mathrm{NO}_{x}\right)$. In regions with net ozone destruction the available $\mathrm{NO}_{x}$ is below the threshold value at which production and destruction of $\mathrm{O}_{3}$ balance. While threshold $\mathrm{NO}$ values increase with altitude, in the upper troposphere $\mathrm{NO}_{x}$ concentrations are generally higher due to the integral effect of convective precursor transport from the boundary layer, downward transport from the stratosphere and $\mathrm{NO}_{x}$ produced by lightning. Two case studies indicate that in fresh convective outflow of electrified thunderstorms net ozone production is enhanced by a factor 5-6 compared to the undisturbed upper tropospheric background. The chemistry-transport model MATCH-MPIC generally reproduces the pattern of observation-based net ozone tendencies but mostly underestimates the magnitude
\end{abstract}

of the net tendency (for both net ozone production and destruction).

\section{Introduction}

Ozone plays a pivotal role in the oxidizing capacity of the troposphere. Besides being an oxidizing agent itself, photolysis of $\mathrm{O}_{3}$ at wavelengths less than $340 \mathrm{~nm}$ produces $\mathrm{O}\left({ }^{1} \mathrm{D}\right)$, whose subsequent reaction with water vapour yields two $\mathrm{OH}$ radicals, the dominant oxidant in the troposphere. Based on $\mathrm{O}_{3}$ profiles in the troposphere, Junge (1963) argued that tropospheric ozone stems from downward transport from the stratosphere and is destroyed at the surface by deposition. But in the 1960s, studies indicated that tropospheric ozone is to a large extent due to in situ photochemical production, similar to the Los Angeles smog (Haagen-Smit and Fox, 1956; Leighton, 1961). A chemical mechanism for the photochemical production of tropospheric ozone was proposed by Chameides and Walker (1973) and Crutzen (1973) after the identification of a major tropospheric $\mathrm{OH}$ source by Levy (1971). Budget calculations based on atmospheric chemistry-transport modelling (e.g. Wild, 2007; Wu et al., 2007; Stevenson et al., 2006; von Kuhlmann et al., 2003) indicate that approximately $390-850 \mathrm{Tg} \mathrm{yr}^{-1}$ of tropospheric $\mathrm{O}_{3}$ are due to stratosphere-troposphere transport, 670$1180 \mathrm{Tg} \mathrm{yr}^{-1}$ are destroyed by deposition to the surface and -90 to $+670 \mathrm{Tg} \mathrm{yr}^{-1}$ are due to photochemical net ozone production (NOP) in the troposphere (von Kuhlmann et al., 
2003; Lelieveld and Dentener, 2000). The NOP itself is a delicate balance between two very large numbers (Lelieveld and Dentener, 2000; von Kuhlmann et al., 2003): ozone production $\mathrm{P}\left(\mathrm{O}_{3}\right)$ at $\sim 3000-5000 \mathrm{Tg} \mathrm{yr}^{-1}$ and $\mathrm{O}_{3}$ destruction $L\left(\mathrm{O}_{3}\right)$ at slightly less, $\sim 2500-4500 \mathrm{Tg} \mathrm{yr}^{-1}$. The discussion about the relative strength of stratosphere-troposphere exchange vs. NOP for tropospheric ozone is not yet resolved in detail. Gross production and destruction of ozone in a global model are based on the applied chemical mechanism, emissions of precursors and their subsequent distribution due to transport. Since stratosphere-troposphere transport of $\mathrm{O}_{3}$ depends on the gradient of $\mathrm{O}_{3}$ between the lower stratosphere and upper troposphere, this process also depends on and influences photochemistry especially in the upper troposphere. Therefore, uncertainties in the models' photochemical ozone production have a strong influence on estimates of the amount of $\mathrm{O}_{3}$ imported from the stratosphere. Furthermore, in chemical transport models (CTMs) and chemistry general circulation models (CGCMs) the stratospheric source of $\mathrm{O}_{3}$ is often highly parameterized, e.g. with prescribed $\mathrm{O}_{3}$ concentrations in the lower stratosphere to reproduce measured ozone profiles.

Tropospheric $\mathrm{O}_{3}$ production is initiated by the oxidation of $\mathrm{CO}$ and volatile organic compounds by the $\mathrm{OH}$ radical:

$\mathrm{CO}+\mathrm{OH}\left(+\mathrm{O}_{2}\right) \rightarrow \mathrm{HO}_{2}+\mathrm{CO}_{2}$,

$\mathrm{CH}_{4}+\mathrm{OH}+\left(\mathrm{O}_{2}\right) \rightarrow \mathrm{CH}_{3} \mathrm{O}_{2}+\mathrm{H}_{2} \mathrm{O}$,

$\mathrm{RH}+\mathrm{OH}+\left(\mathrm{O}_{2}\right) \rightarrow \mathrm{RO}_{2}+\mathrm{H}_{2} \mathrm{O}$.

The resulting peroxy radicals $\mathrm{HO}_{2}, \mathrm{CH}_{3} \mathrm{O}_{2}$ and $\mathrm{RO}_{2}$ subsequently react with $\mathrm{NO}$ to produce $\mathrm{NO}_{2}$ :

$\mathrm{HO}_{2}+\mathrm{NO} \rightarrow \mathrm{NO}_{2}+\mathrm{OH}$,

$\mathrm{CH}_{3} \mathrm{O}_{2}+\mathrm{NO}\left(+\mathrm{O}_{2}\right) \rightarrow \mathrm{NO}_{2}+\mathrm{HO}_{2}+\mathrm{HCHO}$,

$\mathrm{RO}_{2}+\mathrm{NO}+\left(\mathrm{O}_{2}\right) \rightarrow \mathrm{NO}_{2}+\mathrm{HO}_{2}+$ carbonyl.

Subsequently, the $\mathrm{NO}_{2}$ can be photolysed to recycle $\mathrm{NO}$ and produce $\mathrm{O}_{3}$ :

$\mathrm{NO}_{2}+h v(\lambda<420 \mathrm{~nm})+\left(\mathrm{O}_{2}\right) \rightarrow \mathrm{NO}+\mathrm{O}_{3}$.

In remote regions where VOC concentrations other than $\mathrm{CH}_{4}$ are low the production of $\mathrm{O}_{3}$ can be approximated by

$P\left(\mathrm{O}_{3}\right)=k(4)\left[\mathrm{HO}_{2}\right][\mathrm{NO}]+k(5)\left[\mathrm{CH}_{3} \mathrm{O}_{2}\right][\mathrm{NO}]$,

with $k(4)$ and $k(5)$ being the temperature-dependent rate constant of Reactions (R4) and (R5). Chemical destruction of $\mathrm{O}_{3}$ is either due to photolysis or reaction with $\mathrm{OH}, \mathrm{HO}_{2}$ or an alkene:

$$
\begin{aligned}
& \mathrm{O}_{3}+h v(\lambda<340 \mathrm{~nm}) \rightarrow \mathrm{O}\left({ }^{1} \mathrm{D}\right)+\mathrm{O}_{2}, \\
& \mathrm{O}_{3}+\mathrm{OH} \rightarrow \mathrm{HO}_{2}+\mathrm{O}_{2}, \\
& \mathrm{O}_{3}+\mathrm{HO}_{2} \rightarrow \mathrm{OH}+2 \mathrm{O}_{2}, \\
& \mathrm{O}_{3}+\text { alkene } \rightarrow \text { products }+\mathrm{O}_{2} .
\end{aligned}
$$

Whether Reaction $(\mathrm{R} 8)$ results in a permanent loss of $\mathrm{O}_{3}$ depends on the fate of the electronically excited $\mathrm{O}\left({ }^{1} \mathrm{D}\right)$ radical.
Reaction of $\mathrm{O}\left({ }^{1} \mathrm{D}\right)$ with either $\mathrm{N}_{2}$ or $\mathrm{O}_{2}$ leads to deactivation and subsequent reformation of $\mathrm{O}_{3}$, but reaction with water vapour yields two $\mathrm{OH}$ radicals, leading to $\mathrm{O}_{3}$ loss:

$\mathrm{O}\left({ }^{1} \mathrm{D}\right)+\mathrm{H}_{2} \mathrm{O} \rightarrow 2 \mathrm{OH}$,

$\mathrm{O}\left({ }^{1} \mathrm{D}\right)+\mathrm{O}_{2}\left(+\mathrm{O}_{2}\right) \rightarrow \mathrm{O}_{3}+\mathrm{O}_{2}$,

$\mathrm{O}\left({ }^{1} \mathrm{D}\right)+\mathrm{N}_{2}\left(+\mathrm{O}_{2}\right) \rightarrow \mathrm{O}_{3}+\mathrm{N}_{2}$.

The branching ratio among the Reactions (R12a) and (R12b) mainly depends on the water vapour concentrations and is thus altitude dependent.

In remote regions the reaction with alkenes can be neglected and the ozone loss $L\left(\mathrm{O}_{3}\right)$ is given by Reactions (R8)(R10), with Reaction (R8) weighted by the branching ratio $\alpha$ :

$$
\begin{aligned}
L\left(\mathrm{O}_{3}\right)= & \alpha J \mathrm{O}\left({ }^{1} \mathrm{D}\right)\left[\mathrm{O}_{3}\right]+k(9)[\mathrm{OH}]\left[\mathrm{O}_{3}\right] \\
& +k(10)\left[\mathrm{HO}_{2}\right]\left[\mathrm{O}_{3}\right]
\end{aligned}
$$

where $J \mathrm{O}\left({ }^{1} \mathrm{D}\right)$ is the $\mathrm{O}_{3}$ photolysis rate and $\alpha$ is given by

$\alpha=\frac{k(12 \mathrm{a})\left[\mathrm{H}_{2} \mathrm{O}\right]}{k(12 \mathrm{a})\left[\mathrm{H}_{2} \mathrm{O}\right]+k(12 \mathrm{~b})\left[\mathrm{O}_{2}\right]+k(12 \mathrm{c})\left[\mathrm{N}_{2}\right]}$.

The branching ratio $\alpha$ is typically of the order of 1 to $15 \%$ for the upper troposphere and the boundary layer, respectively.

The net ozone production rate (NOPR) in $\mathrm{ppbv} \mathrm{h}^{-1}$ is defined as the difference between production and loss:

$\mathrm{NOPR}=P\left(\mathrm{O}_{3}\right)-L\left(\mathrm{O}_{3}\right)$

NOPR is nonlinear with respect to NO and peroxy radicals. This nonlinearity arises because $\mathrm{RO}_{x}$ and $\mathrm{NO}_{x}$ drive ozone production (Reactions R4-R6) but also terminate free radical chemistry (e.g. Pusede et al., 2015):

$$
\begin{aligned}
& \mathrm{NO}_{2}+\mathrm{OH}+\mathrm{M} \rightarrow \mathrm{HNO}_{3}+\mathrm{M}, \\
& \mathrm{NO}_{2}+\mathrm{RO}_{2}+\mathrm{M} \rightarrow \mathrm{NO}_{2} \mathrm{RO}_{2}+\mathrm{M}, \\
& \mathrm{OH}+\mathrm{HO}_{2} \rightarrow \mathrm{H}_{2} \mathrm{O}+\mathrm{O}_{2}, \\
& \mathrm{HO}_{2}+\mathrm{HO}_{2} \rightarrow \mathrm{H}_{2} \mathrm{O}_{2}+\mathrm{O}_{2}, \\
& \mathrm{CH}_{3} \mathrm{O}_{2}+\mathrm{HO}_{2} \rightarrow \mathrm{CH}_{3} \mathrm{OOH}+\mathrm{O}_{2} .
\end{aligned}
$$

Here we neglect the loss of $\mathrm{NO}_{2}$ due to Reactions (R13) and (R14) in Eq. (4). This is justified by the overall low $\mathrm{NO}_{x}$ concentrations above the continental boundary layer. Reactions (R15) to (R17) will affect $\mathrm{HO}_{x}$ levels and would have to be taken into account to calculate their concentrations using a box model. In this study we will use in situ observations of $\mathrm{OH}$ and $\mathrm{HO}_{2}$ instead.

The threshold NO concentration, at which ozone production and loss are equal, can be calculated by setting

$$
P\left(\mathrm{O}_{3}\right)=L\left(\mathrm{O}_{3}\right)
$$

and re-arranging for $\mathrm{NO}$ :

$$
\mathrm{NO}_{\mathrm{th}}=\frac{\alpha J\left(\mathrm{O}^{1} \mathrm{D}\right)\left[\mathrm{O}_{3}\right]+k(10)\left[\mathrm{HO}_{2}\right]\left[\mathrm{O}_{3}\right]+k(9)[\mathrm{OH}]\left[\mathrm{O}_{3}\right]}{k(4)\left[\mathrm{HO}_{2}\right]+k(5)\left[\mathrm{CH}_{3} \mathrm{O}_{2}\right]} .
$$


With Reaction (R4) being approximately 4000 times faster than Reaction (R10) a typical range for $\mathrm{NO}_{\text {th }}$ is $10-20$ pptv at an ozone concentration of about $50 \mathrm{ppbv}$. Below this $\mathrm{NO}_{\text {th }}$ concentration $\mathrm{O}_{3}$ destruction prevails, while net production occurs at higher NO concentrations.

Model studies indicate that chemical $\mathrm{O}_{3}$ destruction is generally found in the lower troposphere over the oceans due to low $\mathrm{NO}$ and high $\mathrm{H}_{2} \mathrm{O}$ concentrations, while generally higher $\mathrm{NO}_{x}$ concentrations in the continental boundary layer lead to net $\mathrm{O}_{3}$ production (Klonecki and Levy, 1997). Over the oceans $\mathrm{O}_{3}$ loss extends to the free troposphere, while enhanced $\mathrm{NO}_{x}$ due to lightning, convective up-lift from anthropogenic or biomass burning sources and downward transport from the stratosphere leads to $\mathrm{O}_{3}$ production in the free troposphere and tropopause region (Roelofs and Lelieveld, 1997). This difference between oceanic and continental free troposphere vanishes in the upper troposphere, where $\mathrm{O}_{3}$ production prevails (Klonecki and Levy, 1997; von Kuhlmann et al., 2003). Studies that infer net ozone production at least in part from in situ measurements are rare and often limited to the boundary layer (Ren et al., 2013; Liu et al., 2012; Sommariva et al., 2011; Kleinman et al., 2005; Fischer et al., 2003; Kanaya et al., 2002; Kleinman, 2000; Zanis et al., 2000; Penkett et al., 1997; Cantrell et al., 1996). A number of studies based on aircraft measurements have been performed, using in situ $\mathrm{O}_{3}, \mathrm{CO}, \mathrm{NO}_{x}$, volatile organic compounds (VOCs) and radiation measurements in combination with a box model to calculate $\mathrm{HO}_{x}$ and $\mathrm{RO}_{x}$ radical levels to study NOPR in the free troposphere (Kuhn et al., 2010; Kondo et al., 2004; Davis et al., 2003; DiNunno et al., 2003; Ko et al., 2003; Reeves et al., 2002; Olson et al., 2001; Schultz et al., 1999; Crawford et al., 1997a, b; Davis et al., 1996; Jacob et al., 1996). NOPR studies based on in situ $\mathrm{HO}_{x}$ or $\mathrm{RO}_{x}$ measurements by aircraft have been performed by Olson et al. (2012), Ren et al. (2008), and Cantrell et al. (2003a, b). Carzola and Brune (2010) described the application of an in situ instrument to measure ozone production, while estimating the NOPR requires in situ measurements of radicals $\left(\mathrm{OH}, \mathrm{HO}_{2}, \mathrm{RO}_{2}\right)$, nitrogen oxide $(\mathrm{NO})$ and photolysis rates (i.e. $\left.J\left(\mathrm{O}^{1} \mathrm{D}\right)\right)$ in addition to ozone and water vapour. Here we present airborne in situ measurements of radicals and ozone precursors over the tropical rainforest in South America during the GABRIEL (Guyanas Atmosphere-Biosphere exchange and Radicals Intensive Experiment with a Learjet) campaign in October 2005, and compare with a series of north-south transects over Europe in the extratropical troposphere as part of the HOOVER (HOx OVer EuRope) campaign in 2006 and 2007. For the first time the NOPR over the tropical rainforest in South America as well as over Europe is evaluated based only on in situ measurement data (except peroxy radicals) and compared to a 3-D chemical transport model.

\section{Methods}

\subsection{GABRIEL and HOOVER measurements}

The GABRIEL campaign took place in October 2005 over the tropical rainforest in French Guiana and Suriname. A total of 10 measurement flights, each between 3 and $3.5 \mathrm{~h}$ long, were performed between 3 and $6^{\circ} \mathrm{N}$ and 59 to $51^{\circ} \mathrm{W}$ at altitudes between 300 and $9000 \mathrm{~m}$ (Fig. 1a). All flights followed a similar pattern, with take-off from Zanderij airport (Surinam; $5.3^{\circ} \mathrm{N}, 55.1^{\circ} \mathrm{W}$ ), followed by a high-altitude stretch east over the Atlantic Ocean, and a descent into the marine boundary layer off the east coast of South America. Turning west the aircraft followed the main wind direction inland, performing flights in and out of the continental boundary layer over the rainforest. Finally, before landing at the home base a high-altitude profile was flown over Suriname. Additionally, similar flight profiles were performed in the $\mathrm{N}-$ $\mathrm{S}$ direction. Take-off times of the flights were varied over the campaign in order to investigate diurnal variations. Details of the scientific objectives, measurement and model results can be found in Lelieveld et al. (2008) and the GABRIEL special issue in Atmospheric Chemistry and Physics (http: //www.atmos-chem-phys.net/special_issue88.html).

HOOVER consisted of a total of two measurement campaigns in October 2006 and July 2007, composed of four measurement flights each. The measurements covered Europe from 40 to $75^{\circ} \mathrm{N}$ between 8 and $15^{\circ} \mathrm{E}$ and up to a maximum altitude of $12 \mathrm{~km}$ (Fig. 1b). From the home base Hohn (Germany; 54.2 ${ }^{\circ} \mathrm{N}, 9.3^{\circ} \mathrm{E}$ ) regular research flights were performed southward with a stop-over at Bastia airport, Corsica (France; $42.2^{\circ} \mathrm{N}, 9.29^{\circ} \mathrm{E}$ ), and northward with a stop-over at Kiruna airport (Sweden; 67.5 $\mathrm{N}, 20.2^{\circ} \mathrm{E}$ ). The majority of the flights were performed in the upper troposphere, but regular profiles were flown in and out of the home and stop-over bases, as well as approximately half way towards the respective destination in either southern Germany or northern Scandinavia. Additional flights in summer 2007 were directed to the Arctic (Svalbard, Norway; $78.1^{\circ} \mathrm{N}$, $15.3^{\circ} \mathrm{E}$ ) and two flights over central Germany to study the influence of deep convection. Details about the campaigns can be found in two previous publications (Klippel et al., 2011; Regelin et al., 2013).

\subsection{Observations}

During both campaigns a Learjet 35A from GFD (Hohn, Germany) was used. This jet aircraft has a range of $4070 \mathrm{~km}$ and a maximum flight altitude of approximately $14 \mathrm{~km}$. In the present configuration both the horizontal and vertical range were limited due to the use of two wing pods housing additional instrumentation. The scientific instrumentation was similar during both campaigns. It consisted of a chemiluminescence detector (ECO Physics CLD 790 SR, Switzerland) for $\mathrm{NO}, \mathrm{NO}_{2}$ and $\mathrm{O}_{3}$ measurements (Hosaynali Beygi 

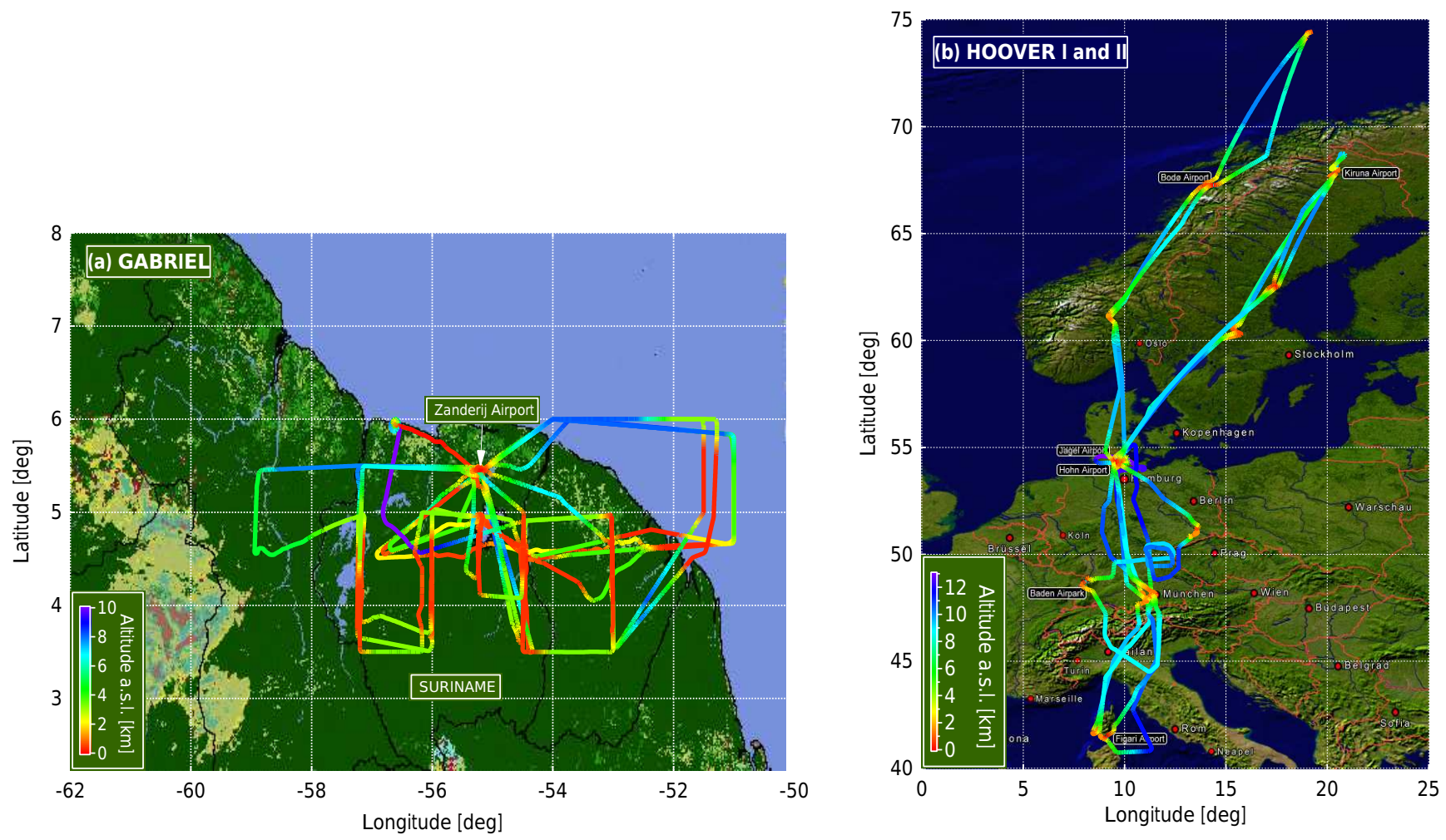

Figure 1. Flight tracks during GABRIEL (a) and HOOVER I and II (b).

et al., 2011), a set of upward- and downward-looking $2 \pi$ steradian filter radiometers for $J\left(\mathrm{NO}_{2}\right)$ measurements (Meteorologie Consult $\mathrm{GmbH}$, Germany), a quantum cascade laser IR-absorption spectrometer for $\mathrm{CO}, \mathrm{CH}_{4}$ and $\mathrm{HCHO}$ measurements (Schiller et al., 2008), a dual-enzyme fluorescence monitor (model AL2001 CA peroxide monitor, AeroLaser $\mathrm{GmbH}$, Germany) to measure $\mathrm{H}_{2} \mathrm{O}_{2}$ and organic hydroperoxides (Klippel et al., 2011), a laser-induced fluorescence (LIF) instrument for simultaneous measurements of $\mathrm{OH}$ and $\mathrm{HO}_{2}$ (Martinez et al., 2010; Regelin et al., 2013), a non-dispersive IR-absorption instrument (model LI-6262, LI-COR Inc., USA) for $\mathrm{CO}_{2}$ and $\mathrm{H}_{2} \mathrm{O}$ measurements (Gurk et al., 2008), a proton transfer reaction mass spectrometer (PTR-MS, Ionicon, Austria) for partially oxidized volatile organic compounds measurements and a series of canisters for post-flight analysis of non-methane hydrocarbons (Colomb et al., 2006). Here a subset $\left(\mathrm{O}_{3}, \mathrm{NO}, \mathrm{CO}, \mathrm{CH}_{4}, \mathrm{H}_{2} \mathrm{O}, \mathrm{OH}\right.$, $\mathrm{HO}_{2}$ and $\left.J\left(\mathrm{NO}_{2}\right)\right)$ of these measurements will be used to deduce NOPR values. Details about the performance of those measurements with respect to time resolution, precision, detection limits and total uncertainties can be found in Table 1 .

\subsection{Estimating peroxy radical concentrations and $J\left(\mathbf{O}^{1} \mathrm{D}\right)$}

Most species that are needed for an evaluation of Eqs. (1)(4) are provided by in situ observations with the exception of
$\left[\mathrm{CH}_{3} \mathrm{O}_{2}\right]$ in Eq. (1) and $J\left(\mathrm{O}^{1} \mathrm{D}\right)$ in Eq. (2), which have to be derived from other measurements.

As mentioned in the Introduction, we assume that in remote areas outside of the continental boundary layer, the concentrations of other volatile organic compounds besides methane are low, so that $\mathrm{CH}_{3} \mathrm{O}_{2}$ is the only organic peroxy radical at significant concentrations in view of $\mathrm{O}_{3}$ formation. According to Reactions (R1) and (R2) the production rates for $\mathrm{HO}_{2}$ and $\mathrm{CH}_{3} \mathrm{O}_{2}$ radicals are proportional to the concentrations of $\mathrm{CO}$ and $\mathrm{CH}_{4}$, respectively. Since the photochemical lifetimes of both radicals with respect to their reaction with NO (Reactions R4, R5) or selfreactions leading to peroxides are similar (Hosaynali Beygi et al., 2011; Klippel et al., 2011), we assume that the ratio of $\mathrm{HO}_{2} / \mathrm{CH}_{3} \mathrm{O}_{2}$ is proportional to their production rates $k_{(\mathrm{CO}+\mathrm{OH})}[\mathrm{CO}][\mathrm{OH}] / k_{\left(\mathrm{CH}_{4}+\mathrm{OH}\right)}\left[\mathrm{CH}_{4}\right][\mathrm{OH}]$, so that the concentration of $\mathrm{CH}_{3} \mathrm{O}_{2}$ can be deduced from Eq. (5):

$\left[\mathrm{CH}_{3} \mathrm{O}_{2}\right]=\frac{k(2)\left[\mathrm{CH}_{4}\right]}{k(1)[\mathrm{CO}]}\left[\mathrm{HO}_{2}\right]$.

Thus, using measured mixing ratios for $\mathrm{CO}, \mathrm{CH}_{4}$ and $\mathrm{HO}_{2}$ and the temperature-dependent rate coefficients for Reactions (R1) and (R2), the mixing ratio of $\mathrm{CH}_{3} \mathrm{O}_{2}$ can be estimated. Hosaynali Beygi et al. (2011) have used this approach in the marine boundary layer and compared it to both box model and 3-D chemical transport model simulations in order to demonstrate the applicability of Eq. (7) in remote re- 
Table 1. Precision, accuracy and detection limit of the in situ measurements used to deduce NOPR.

\begin{tabular}{lrrr}
\hline & Precision $(1 \sigma)$ & Accuracy & Detection limit \\
\hline$J\left(\mathrm{NO}_{2}\right)$ & $1 \%$ & $10 \%$ & \\
$\mathrm{CO}$ & $<1 \%$ & $1 \%$ & \\
$\mathrm{CH}_{4}$ & $<1 \%$ & $1 \%$ & \\
$\mathrm{H}_{2} \mathrm{O}$ & & $5 \%$ & $200 \mathrm{ppmv}$ \\
$\mathrm{O}_{3}$ & $4 \%$ & $2 \%$ & $2 \mathrm{ppbv}$ \\
$\mathrm{NO}$ & $7 \%$ & $12 \%$ & $5 \mathrm{pptv}$ \\
$\mathrm{OH}$ & $7 \%$ & $18 \%$ & $0.02 \mathrm{pptv}$ \\
$\mathrm{HO}_{2}$ & $1 \%$ & $18 \%$ & $0.07 \mathrm{pptv}$ \\
\hline
\end{tabular}

gions. We expect this to also hold for the free troposphere. In the continental boundary layer and in the outflow of deep convective clouds, Reaction (R4) will most probably underestimate peroxy radical concentrations and thus $\mathrm{O}_{3}$ production according to Eq. (1).

The $\mathrm{O}_{3}$ photolysis rate $J\left(\mathrm{O}^{1} \mathrm{D}\right)$ and $J\left(\mathrm{NO}_{2}\right)$ were calculated with the radiation transfer model TUV (https://www2.acom.ucar.edu/modeling/troposphericultraviolet-and-visible-tuv-radiation-model) (Madronich and Flocke, 1999) and scaled to the observed $J\left(\mathrm{NO}_{2}\right)$ values. The scaling accounts for the effects of clouds that are not simulated by the TUV model, in particular enhanced up-welling radiation when flying over larger cloud decks. This method is not ideal, since it does not take into account the wavelength dependency of either transmission or reflection by clouds. Shetter et al. (2003) indicate that the TUV simulation of $J\left(\mathrm{NO}_{2}\right)$ and $J\left(\mathrm{O}^{1} \mathrm{D}\right)$ compared to observations are accurate to within $6-18$ and $6-11 \%$, respectively.

\subsection{MATCH simulations}

To compare the experimentally derived NOPR values with model simulations the 3-D chemistry transport model MATCH-MPIC (Lawrence et al., 2003; von Kuhlmann et al., 2003) (hereinafter referred to simply as MATCH) has been used. The model is driven by meteorological data from the National Center for Environmental Prediction (NCEP) Global Forecast System (GFS). The chemical scheme, including details of the non-methane hydrocarbon chemistry, is described in von Kuhlmann et al. (2003). The model was run with a resolution of approximately $2.8^{\circ} \times 2.8^{\circ}$ in the horizontal direction and includes 42 vertical $\sigma$ levels up to $2 \mathrm{hPa}$. Emissions from anthropogenic and natural sources are based on the Emission Database for Global Atmospheric Research EDGAR v3.2 (Olivier et al., 2002). The model has been used for chemical weather forecasting to guide the day-today flight planning during GABRIEL and HOOVER. Here we used post-campaign analysis simulations to produce virtual flights through the model along the actual aircraft trajectories, as done in Fischer et al. (2006). From the model results NOPR values derived from a full chemistry scheme including also higher-order peroxy radicals have been calculated for every point along the flight tracks.

\section{Results}

\subsection{Data processing}

In the following, net ozone production rates in $\mathrm{ppbv} \mathrm{h}^{-1}$ are calculated from in situ data according to Eq. (4), with ozone production $P\left(\mathrm{O}_{3}\right)$ calculated from Eq. (1), including Eq. (7) for $\left[\mathrm{CH}_{3} \mathrm{O}_{2}\right]$ and ozone loss $L\left(\mathrm{O}_{3}\right)$ from Eq. (2) with Eq. (3) for $\alpha$. A filter $\left(\mathrm{O}_{3}<100 \mathrm{ppbv}\right)$ was applied to the data to exclude direct stratospheric influence. Data from two flights dedicated to the investigation of deep convection (GABRIEL flight GAB 08 on 12 October 2005 (Bozem et al., 2014) and HOOVER II flight 07 on 19 July 2007) were not included, and will be discussed separately. For the remaining data tropospheric NOPR rates were calculated along the flight tracks using merged data sets with a time resolution of $30 \mathrm{~s}$. Instead of presenting the NOPR data as a time series for individual flights, we make use of the sampling strategy followed in the two campaigns. As can be seen in Fig. 1, flights during GABRIEL were mostly oriented from east to west (in Fig. 1a), while flights during HOOVER had a north-south orientation (Fig. 1b). Therefore, all NOPR data from the individual flights have been binned into altitude-longitude (GABRIEL) and altitude-latitude (HOOVER) bins. The bin size is $1 \mathrm{~km}$ in altitude, $0.5^{\circ}$ in longitude (GABRIEL) and $2.5^{\circ}$ in latitude (HOOVER). NOPR values are presented as median values for a given altitude/longitude (GABRIEL) or altitude/latitude (HOOVER) bin. Additionally, the $1 \sigma$ standard deviation of the individual NOPR values in the respective bin is given as a measure of the atmospheric variability. Please note that median values are used throughout the paper for NOPR calculations instead of mean values, in order to limit the influence of extreme events. Such events mainly influence NOPR calculations at the highest and lowest altitudes, and are predominantly due to NO spikes associated with aircraft emissions in the proximity of the airports or in flight corridors. Since these events are rare and vary strongly in terms of NO enhancement, we do not filter the data, but instead use median values that are not affected by occasional peak values. The same applies to values below the detection limit (e.g. for radicals) that might otherwise bias the calculations. Differences between mean and median NOPR values are insignificant during GABRIEL and up to a factor of 2 in the continental boundary layer during HOOVER I as shown in the respective figures.

Since NOPR values can only be calculated for those bins that have at least one data point for each trace gas species needed in Eqs. (1)-(7) $\left(\mathrm{O}_{3}, \mathrm{NO}, \mathrm{CO}, \mathrm{CH}_{4}, \mathrm{H}_{2} \mathrm{O}, \mathrm{OH}, \mathrm{HO}_{2}\right.$ and $J\left(\mathrm{NO}_{2}\right)$ ), missing data strongly limit data coverage. Data gaps during all three campaigns are mainly due to the low duty cycle of the TRISTAR instrument used to sequentially 
measure $\mathrm{HCHO}, \mathrm{CO}$ and $\mathrm{CH}_{4}$. Due to a longer time spent on measuring $\mathrm{HCHO}$ and regular $\mathrm{HCHO}$ background measurements, only $10 \mathrm{~min}$ per hour $(16 \%)$ were dedicated to the measurement of $\mathrm{CO}$ and $\mathrm{CH}_{4}$. Additional data gaps during GABRIEL arose from a partial lack of $\mathrm{H}_{2} \mathrm{O}$ measurements. To overcome this, altitude profiles (median and standard deviation) for $\mathrm{CO}, \mathrm{CH}_{4}$ and $\mathrm{H}_{2} \mathrm{O}$ have been calculated for the GABRIEL data set to substitute missing values by median values from the profiles for a particular altitude bin. This way the available number of NOPR calculations could be increased by a factor of 4 , without changing trends in NOPR for different regions. Similar data gaps for $\mathrm{CO}$ and $\mathrm{CH}_{4}$ during HOOVER I and II have been handled accordingly. These data gaps mainly affect the calculation of $\mathrm{CH}_{3} \mathrm{O}_{2}$ radicals in Eq. (7).

Further, for HOOVER II, nitrogen oxide (NO) data are not available from the flights to and from Corsica; thus, in particular south of the Alps, NOPR calculations cannot be based on in situ data. Based on an additional flight between the home base in northern Germany and northern Italy (HOOVER II flight 06 from Hohn to Baaden Airport (Germany) on 19 July 2007), an average NO profile has been calculated for the southern part of Europe and used as a proxy for missing NO values. Note that data from HOOVER II flight 07 on the same day have not been used, since they were affected by strong convection over southeastern Germany. Uncertainties due to the missing NO data during HOOVER II will be discussed further below. We did not filter the data for the time of the day. All flights were performed during daylight hours between approx. 10:00 and 17:00 local time.

Simulation results for $P\left(\mathrm{O}_{3}\right), L\left(\mathrm{O}_{3}\right)$ and NOPR along the flight trajectories obtained from MATCH have been filtered for stratospheric influence, processed and binned in a similar way as the in situ data and will be presented together with the in situ data.

\subsection{NOPR for GABRIEL}

Figure 2 shows results for NOPR calculations based on in situ measurements (Fig. 2a) and MATCH simulations (Fig. 2c) for the GABRIEL campaign in October 2005. As mentioned above, NOPR values have been calculated along the flight tracks and sampled into bins of $1 \mathrm{~km}$ height and $0.5^{\circ}$ longitude. The median values of NOPR per bin are presented with different colours, ranging from blue (negative NOPR indicating net $\mathrm{O}_{3}$ destruction) to red (positive NOPR indicating net $\mathrm{O}_{3}$ production). The number of data points within a bin is given as a number in the lower left corner. The circle inside the bin is a measure of the variability, with a box filling circle indicating a variability of more than $50 \%$ relative to the median. Note that a variability value is presented even if only two data points are available for an individual bin. Both figures are oriented from west to east, so that data over the Atlantic Ocean are on the right-hand side of the figure. With the South American coastline located between 53.5 and $53.0^{\circ} \mathrm{W}$, bins east of this longitude are representative of marine air masses and bins towards the west represent continental air masses.

In the lowest bins $(0-1 \mathrm{~km}$ altitude) representing the boundary layer, NOPR values indicate a change from $\mathrm{O}_{3}$ destruction in the marine boundary layer $(-0.2$ to $-0.4 \mathrm{ppbv} \mathrm{h}^{-1}$ between 51 and $54^{\circ} \mathrm{W}$ ) towards a highly variable $\mathrm{O}_{3}$ production $\left(0-0.6 \mathrm{ppbv} \mathrm{h}^{-1}\right)$ regime in the continental boundary layer over the tropical rainforest $\left(54\right.$ to $57.5^{\circ} \mathrm{W}$ ) (Fig. 2a). Highest NOPR values are observed at the coast at $52.5-53^{\circ} \mathrm{W}$, due to local pollution enhancing NO (see the discussion of Fig. 3a further below) most probably in the vicinity of Cayenne, the capital of French Guiana. Note that the absolute values for NOPR in the boundary layer, in particular over land, are less reliable, since we do not consider the contributions of higher organic peroxy radicals to ozone production and also neglect an additional $\mathrm{O}_{3}$ sink due to reaction with alkenes, in particular isoprene. In the free troposphere, above $1 \mathrm{~km}$ and below $6 \mathrm{~km}$ altitude, NOPR values are generally negative, with strongest $\mathrm{O}_{3}$ destruction in the first $2 \mathrm{~km}$ above the boundary layer. Above $6 \mathrm{~km}$ there is again a region with slightly positive NOPR and hence net $\mathrm{O}_{3}$ production. In general, above the boundary layer NOPR values exhibit no difference between marine and continental regions. Note that similar results are obtained from calculations based only on the subset of data points for which simultaneous in situ measurements of all species necessary to calculate NOPR are available. Thus, replacing the missing values by median values from average profiles does not change the results significantly. This statement holds also for results from the other campaigns, with the exception of missing $\mathrm{NO}$ measurements south of $55^{\circ} \mathrm{N}$ during HOOVER II. This will be addressed in Sect. 2.4.

The MATCH simulations (Fig. 2c) exhibit similar NOPR tendencies for the different altitude regimes, though the absolute values are generally smaller $\left(-0.2\right.$ and $0.1 \mathrm{ppbvh}^{-1}$, respectively). Also, MATCH simulates net $\mathrm{O}_{3}$ destruction in the continental boundary layer over the tropical rainforest, in contrast to the calculation derived from the in situ observations (Fig. 2a).

To illustrate the differences in NOPR between observations and model simulations, average (median, mean, $1 \sigma$ standard deviation) altitude profiles for the individual production and destruction terms are given in Fig. $2 b$ and $d$ for the observations and the simulations, respectively. Production throughout the troposphere is dominated by the reaction of $\mathrm{NO}$ with $\mathrm{HO}_{2}$ (red dots in Fig. $2 \mathrm{~b}$ and d), while the reaction of $\mathrm{NO}$ with $\mathrm{CH}_{3} \mathrm{O}_{2}$ (red squares) is much smaller by about a factor of 2 . This behaviour is seen in both the observations (Fig. 2b) and the model simulations (Fig. 2d), but the absolute values for the production rates differ by a factor of 2 , with the observations being higher than the simulations. The concentration of $\mathrm{HO}_{2}$ - and thus according to Eq. (7) the concentration of $\mathrm{CH}_{3} \mathrm{O}_{2}$ - decreases with altitude throughout the troposphere by roughly a factor of 10 (Kubistin et al., 2010) 

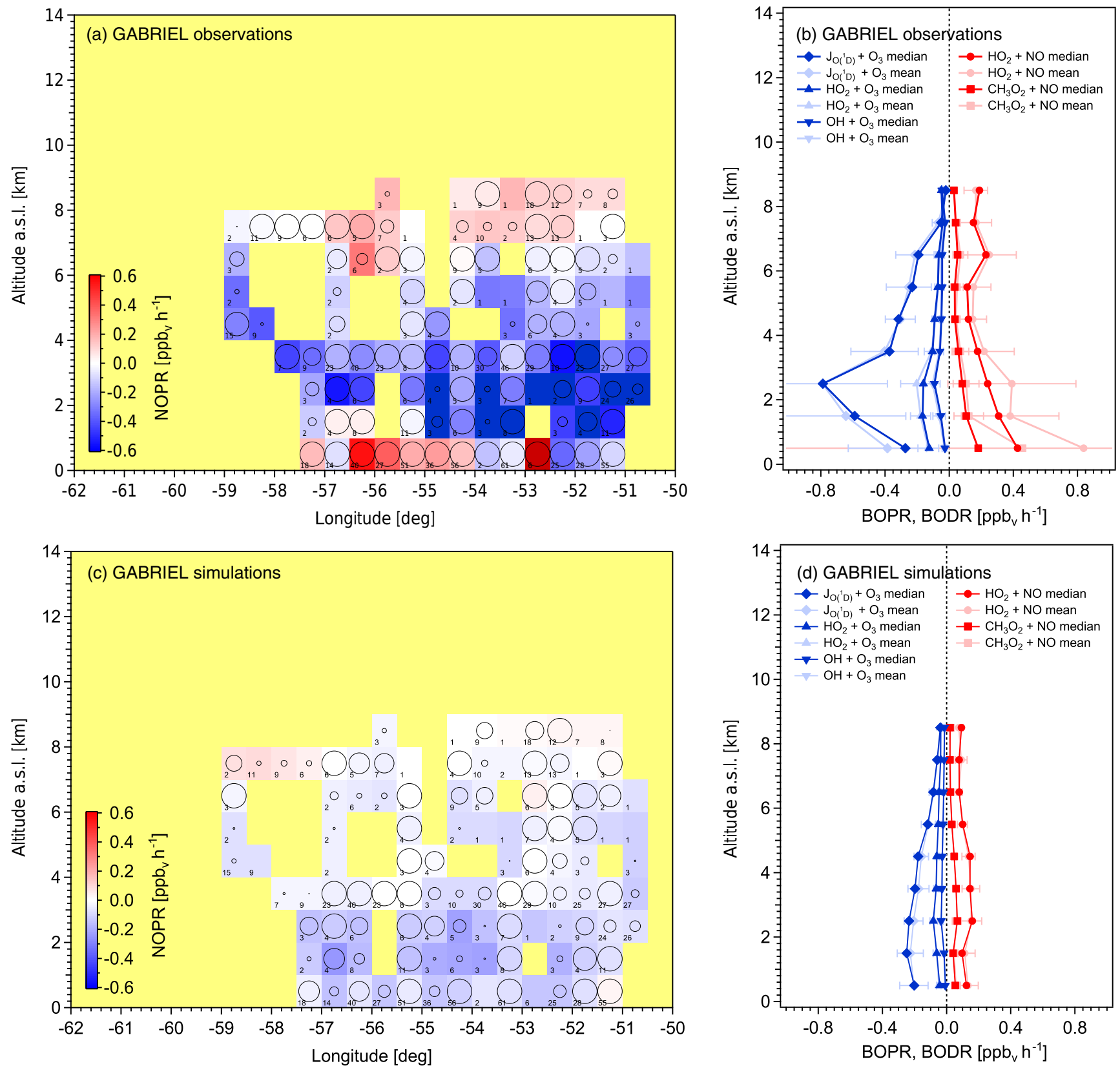

Figure 2. Net ozone production rates (NOPR) in $\mathrm{ppbv} \mathrm{h}^{-1}$ calculated from in situ data (a) and from MATCH simulations (c) for GABRIEL. Altitude profiles of individual production and destruction rates are shown in panels (b) (observations) and (d) (model simulations).

so that the increase in the production rates is mainly due to an increase in NO concentrations, and partly due to the shift in the $\mathrm{NO}_{x}$ partitioning at low temperatures (Brunner et al., 2001; Ziereis et al., 2000).

Ozone destruction is dominated by photolysis up to an altitude of $6 \mathrm{~km}$ (blue dots in Fig. 2b and d) with much higher (up to a factor of 4) destruction rates deduced from the observations (Fig. 2b). The reactions between ozone and either $\mathrm{HO}_{2}$ or $\mathrm{CH}_{3} \mathrm{O}_{2}$ (triangles) are rather constant throughout the troposphere with larger rates (factor of 2) derived from ob- servations compared to the model simulations. It is worth mentioning that the destruction rates are proportional to the ozone concentration. Increasing mixing ratios with altitude thus compensate for the pressure drop leading to almost constant $\mathrm{O}_{3}$ concentrations.

In Fig. 3 the ratio between $\mathrm{NO}$ and $\mathrm{NO}_{\text {th }}$ calculated from Eq. (7) is plotted for in situ data (Fig. 3a) and MATCH simulations (Fig. 3d). According to Eq. (7) the measurementcalculated threshold $\mathrm{NO}$ concentration in the boundary layer is 9 pptv, while it increases to about 20 pptv above the bound- 

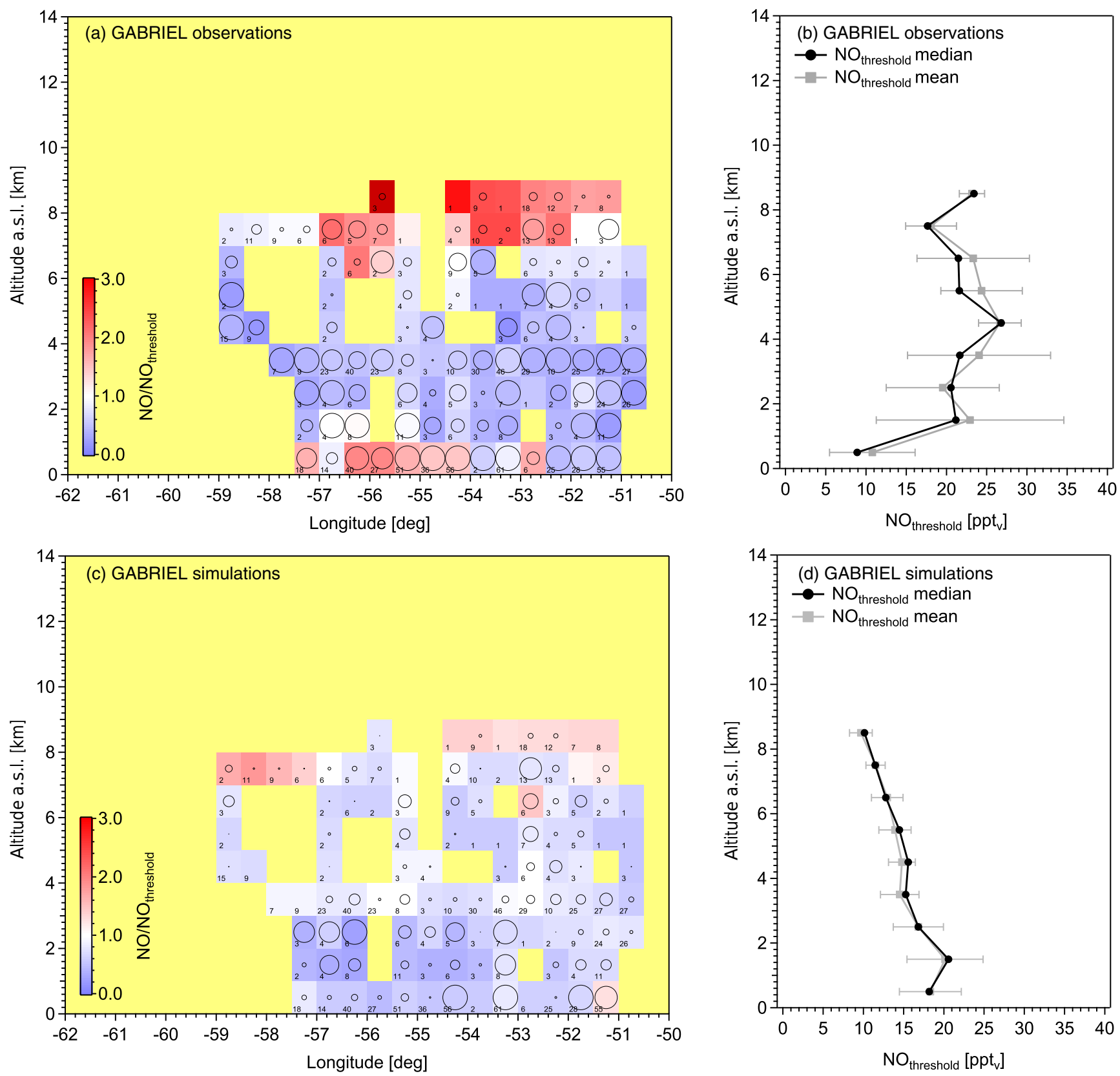

Figure 3. Ratio of $\mathrm{NO}$ to $\mathrm{NO}_{\text {th }}$ deduced from in situ data (a) and MATCH simulations (c) for GABRIEL. Altitude profiles for NO ${ }_{\text {th }}$ are given in panel (b) for the observations and in panel (d) for model simulations.

ary layer (Fig. 3b). This is mainly due to the decrease in observed $\mathrm{HO}_{2}$ and estimated $\mathrm{CH}_{3} \mathrm{O}_{2}$ concentrations above the boundary layer, which leads to an increase in the threshold NO value. Measured NO mixing ratios are higher than the threshold values in the continental boundary layer (approx. 2 times larger), and at altitudes above $6 \mathrm{~km}$ (up to 3 times larger) (Fig. 3a), indicating net ozone production regimes as shown by Fig. 2a.

The evaluation of MATCH shows a slightly different altitude-dependent behaviour of $\mathrm{NO}_{\mathrm{th}}$, with highest values
(21 pptv) in the boundary layer, decreasing almost linearly with altitude to lowest values of $10 \mathrm{pptv}$ at $8 \mathrm{~km}$ (Fig. 3d). This behaviour is due to the underestimation of the reaction of $\mathrm{O}^{1} \mathrm{D}$ with $\mathrm{H}_{2} \mathrm{O}$, most likely due to an underestimation of lower-tropospheric $\mathrm{H}_{2} \mathrm{O}$ concentrations. Fig. 3b shows that simulated NO concentrations in MATCH are almost always lower than the threshold values $\left(\mathrm{NO} / \mathrm{NO}_{\text {th }}\right.$ ratio between 0 and 1), except at the highest altitudes (NO about $50 \%$ higher than $\mathrm{NO}_{\text {th }}$ ), thus explaining the overall negative NOPR values in Fig. 2b. Therefore, the deviations between model sim- 
ulations and in situ data for NOPR are due to differences in the threshold NO levels $\left(\mathrm{NO}_{\mathrm{th}}\right)$ and generally lower $\mathrm{NO}$ concentrations in the model simulations. Discrepancies in $\mathrm{NO}_{\text {th }}$ by the MATCH model are possibly related to the nonmethane hydrocarbon chemistry scheme, which may underestimate radical recycling under low- $\mathrm{NO}_{x}$ conditions and high isoprene (Kubistin et al., 2010; Taraborrelli et al., 2012).

In general, the charts of the $\mathrm{NO}$ to $\mathrm{NO}_{\text {th }}$ ratio resemble the NOPR charts, with ratios larger than unity corresponding to net ozone production and ratios less than unity to ozone destruction. The values also scale quantitatively, illustrating the strong dependency of NOPR on NO mixing ratios. At the rather moderate NO levels in the free troposphere this relationship seems to be linear. This behaviour is also found in the data from the HOOVER campaigns.

\subsection{NOPR for HOOVER I}

Figure 4 shows results for NOPR calculations based on in situ (Fig. 4a) and MATCH simulations (Fig. 4d) for the HOOVER I campaign in October 2006 over Europe. For this campaign the data for NOPR have been combined into $1 \mathrm{~km}$ altitude and $2.5^{\circ}$ latitude bins. The majority of the data are obtained in the upper troposphere, while vertical profiles are restricted to take-offs and landings in airports on Corsica $\left(40-42.5^{\circ} \mathrm{N}\right)$, Hohn $\left(52.5-55^{\circ} \mathrm{N}\right)$ and Kiruna (67.5$\left.70^{\circ} \mathrm{N}\right)$. Additional profiles were flown north and south of the Alps $\left(45-50^{\circ} \mathrm{N}\right)$ and over Sweden $\left(60-62.5^{\circ} \mathrm{N}\right)$. Overall, the in situ data indicate net ozone production $(0.1-$ $0.3 \mathrm{ppbv} \mathrm{h}^{-1}$ ) throughout the troposphere, except at the most northern $\left(0 \mathrm{ppbv} \mathrm{h}^{-1}\right)$ and southern $\left(\sim-0.1 \mathrm{ppbv} \mathrm{h}^{-1}\right)$ parts of the flights. Threshold NO values are between 15 and 20 pptv below $2 \mathrm{~km}$ altitude and approximately $10 \mathrm{pptv}$ between 2 and $10 \mathrm{~km}$. Above that altitude they linearly increase to approx. $35 \mathrm{pptv}$ at $12 \mathrm{~km}$ (Fig. $5 \mathrm{~b}$ ). In regions with net ozone production (NOPR $>0 \mathrm{ppbv} \mathrm{h}^{-1}$ ), measured NO concentrations are up to a factor of 4 higher than $\mathrm{NO}_{\text {th }}$. In the regions with NOPR $\leq 0 \mathrm{ppbv} \mathrm{h}^{-1}$ the measured NO concentration is smaller than $\mathrm{NO}_{\text {th }}$ (Fig. 5a).

MATCH simulations of NOPR (Fig. 4c) exhibit slightly lower values $\left(0-0.1 \mathrm{ppbv} \mathrm{h}^{-1}\right)$ compared to those derived from in situ data, but the general tendencies are reproduced well. Figure $4 \mathrm{~b}$ and $\mathrm{d}$ indicate that this difference between observations and model simulations is mainly due to an underestimation of the $\mathrm{NO}$ plus $\mathrm{HO}_{2}$ reaction (red dots) by the model ( $\sim$ factor of 2 ). The other production term $\left(\mathrm{NO}+\mathrm{CH}_{3} \mathrm{O}_{2}\right)$ is similar for observations and model simulations (red squares). As has been observed for GABRIEL, the almost constant production terms are due to an increase in $\mathrm{NO}$ with altitude, while $\mathrm{HO}_{2}$ and thus $\mathrm{CH}_{3} \mathrm{O}_{2}$ concentrations drop by approximately a factor of 6 (Regelin et al., 2013). Contrary to GABRIEL, ozone photolysis is not the dominant sink (blue squares in Fig. $4 \mathrm{~b}$ and d), but is similar to the other destruction rates $\left(\mathrm{HO}_{2}+\mathrm{O}_{3}\right.$ and $\left.\mathrm{OH}+\mathrm{O}_{3}\right)$. The absolute destruction rates are comparable between ob- servations and model simulations. This similarity of the destruction rates in observations and model simulations is most probably responsible for the similarity of the $\mathrm{NO}_{\text {th }}$ values. The altitude profile of $\mathrm{NO}_{\mathrm{th}}$ derived from observations and MATCH are very similar, with the absolute values below $10 \mathrm{~km}$ being only slightly different (8 pptv from MATCH compared to $10 \mathrm{pptv}$ from the observations) (Fig. 5b and c). As indicated in Fig. 5a and c, $\mathrm{NO} / \mathrm{NO}_{\text {th }}$ values are also comparable. The only exception is the vertical profile over Sweden, where the observations indicate strong ozone production due to high NO concentrations, which are not reproduced by MATCH. Overall, MATCH tends to underestimate NO concentrations throughout the troposphere, possibly related to underestimated vertical mixing of pollution from the boundary layer or missing $\mathrm{NO}_{x}$ reservoir species such as alkyl nitrates in the chemistry scheme.

\subsection{NOPR for HOOVER II}

As mentioned above, NOPR calculations for HOOVER II are strongly affected by the failure of the CLD instrument used for NO measurements on the flights to the south, from Hohn to Corsica and back. Figure 6a shows results for NOPR calculations based on this limited data set. The NOPR calculations based on in situ data are limited to latitudes north of $50^{\circ} \mathrm{N}$. At higher latitudes a similar pattern to that during HOOVER I is observed, with net ozone production in the boundary layer, negligible to negative NOPR in the middle troposphere and a tendency for moderate net ozone production in the upper troposphere. This general pattern is reproduced by MATCH simulations north of $50^{\circ} \mathrm{N}$ as shown in Fig. 6d.

In order to improve the data coverage, in particular south of $50^{\circ} \mathrm{N}$, we used an average NO profile measured on 19 July 2007. On this day, two measurement flights were performed (HOOVER II flights 06 and 07) to study deep convection over southern Germany out of Baaden airport $\left(48.4^{\circ} \mathrm{N}\right.$, $8.4^{\circ} \mathrm{E}$ ). Since no nitric oxide measurements were obtained on the regular flights south, the transfer flight to Baaden airport was extended southward to northern Italy. Thus a limited data set of NO could be obtained south of $50^{\circ} \mathrm{N}$. Profile information is available from a descent north of the Alps close to Oberpfaffenhofen $\left(48.4^{\circ} \mathrm{N}, 11.1^{\circ} \mathrm{E}\right)$ and the landing at Baaden airport. From this data set an average profile was deduced and median values have been used in the calculation of NOPR south of $55^{\circ} \mathrm{N}$ (Fig. 6b). This led to overall negative ozone tendencies throughout the troposphere at latitudes south of $50^{\circ} \mathrm{N}$ in contrast to the MATCH simulations that predict net ozone production (Fig. 6d). Both the model and $\mathrm{NO}_{\text {th }}$ calculations based on in situ data indicate a threshold NO concentration of 15-20 pptv between the boundary layer and approx. $9 \mathrm{~km}$ altitude (with strongly increasing $\mathrm{NO}_{\text {th }}$ above this altitude), with the model calculating slightly smaller values. The MATCH model simulates $\mathrm{NO}$ concentrations south of $55^{\circ} \mathrm{N}$ that are a factor of 2 to 

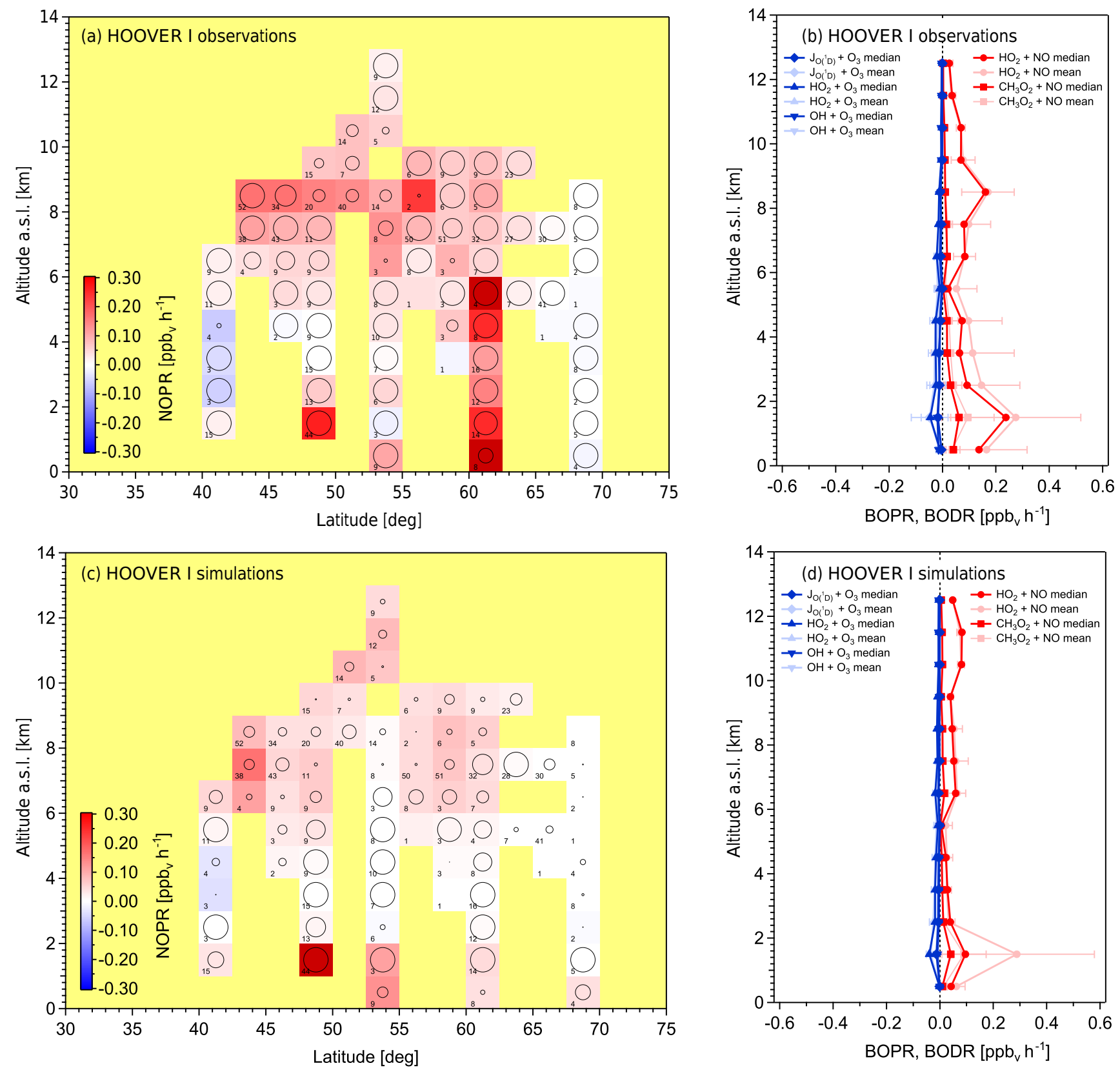

Figure 4. Net ozone production rates (NOPR) in $\mathrm{ppbv} \mathrm{h}^{-1}$ calculated from in situ data (a) and from MATCH simulations (c) for HOOVER I. Altitude profiles of individual production and destruction rates are shown in panel (b) (observations) and panel (d) (model simulations).

3 higher than the simulated $\mathrm{NO}_{\text {th }}$. The $\mathrm{NO}$ values from the HOOVER II flight 06 profile used to fill in data gaps south of $50^{\circ} \mathrm{N}$ are more than $50 \%$ lower than the deduced $\mathrm{NO}_{\text {th }}$ based on in situ observations. Thus the negative ozone tendencies in Fig. 5b are mainly due to an underestimation of NO mixing ratios. Therefore, a sensitivity study was performed by doubling the NO concentrations obtained from the HOOVER II flight 06 profile. The results for NOPR are shown in Fig. 6c. The doubling of NO mixing ratios leads to a shift to positive NOPRs south of $55^{\circ} \mathrm{N}$ and to a much bet- ter agreement with the model simulations shown in Fig. 5d. It should be mentioned that the enhanced $\mathrm{NO}$ mixing ratios are in rather good agreement with $\mathrm{NO}$ measurements obtained over southern Germany and northern Italy in the summer of 2003 as part of the UTOPHIAN-ACT campaign (Stickler et al., 2006). Thus it seems that the NO mixing ratios from the HOOVER II flight 06 profile may not be representative of background NO south of $50^{\circ} \mathrm{N}$. This sensitivity study clearly showed the dominant role of NO for the NOPR calculations for HOOVER II. Taking into account the uncertainty in the 

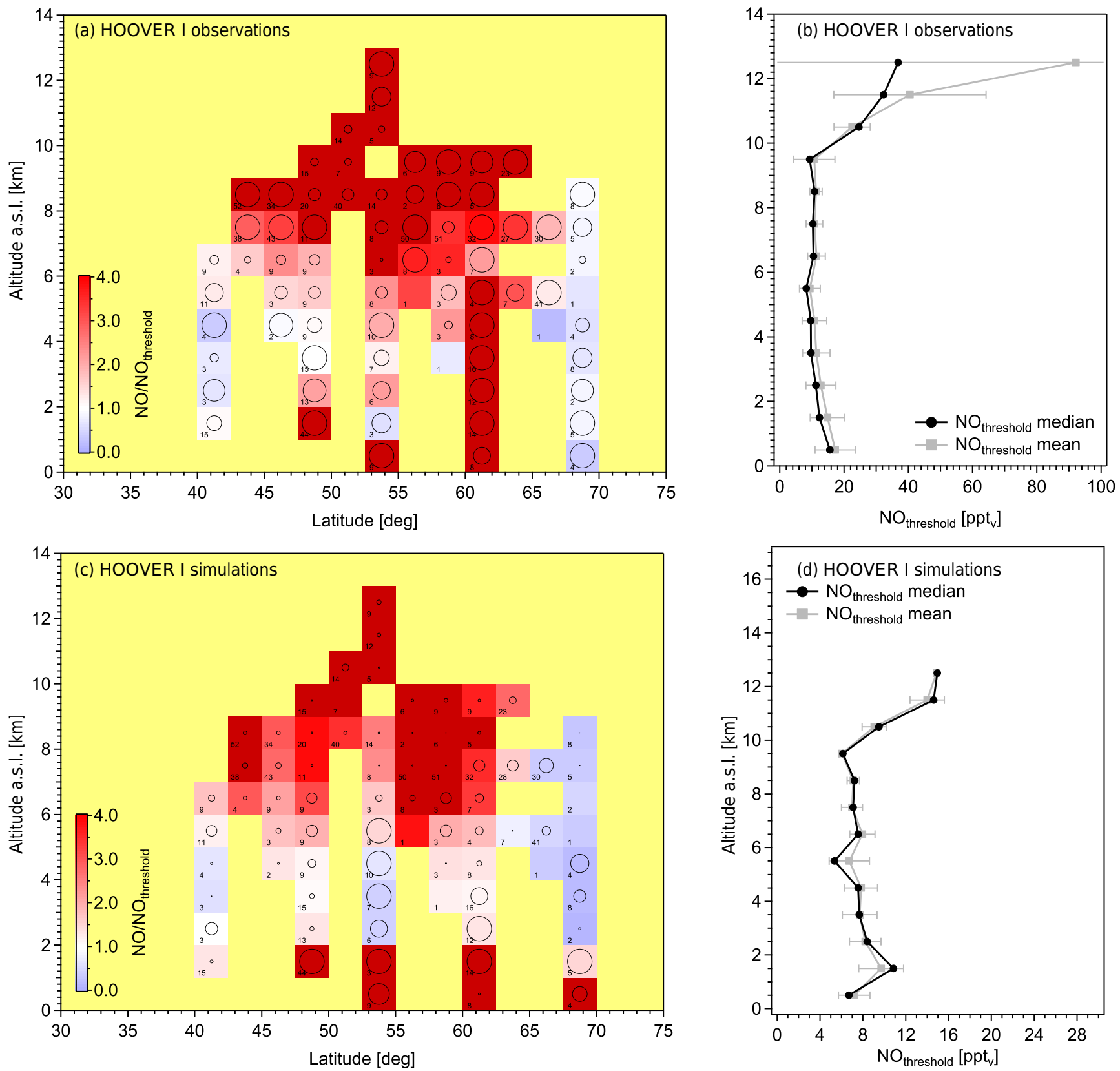

Figure 5. Ratio of $\mathrm{NO}$ to $\mathrm{NO}_{\text {th }}$ deduced from in situ data (a) and MATCH simulations (c) for HOOVER I. Altitude profiles for NO $\mathrm{H}_{\text {th }}$ are given in panel (b) for the observations and in panel (d) for model simulations.

measured $\mathrm{NO}$ data south of $55^{\circ} \mathrm{N}$, it does not make sense to discuss and compare production and destruction terms as in GABRIEL and HOOVER I.

Overall, a general feature of the three missions is a tendency of net ozone production at the highest altitudes, although we calculate strong increases of $\mathrm{NO}_{\text {th }}$ with altitude. For HOOVER II both model simulations and observationbased calculations indicate a doubling of $\mathrm{NO}_{\text {th }}$ between 9 and $11 \mathrm{~km}$ altitude from approx. $20 \mathrm{pptv}$ to more than $40 \mathrm{pptv}$. As mentioned in the previous sections, similar tendencies for
$\mathrm{NO}_{\text {th }}$ were also deduced for HOOVER I and GABRIEL. In order to maintain positive NOPR at high altitudes a strong enhancement of NO above $10 \mathrm{~km}$ is required. In the next section we will discuss the influence of deep convection on NOPR based on two case studies during GABRIEL and HOOVER II, respectively. 

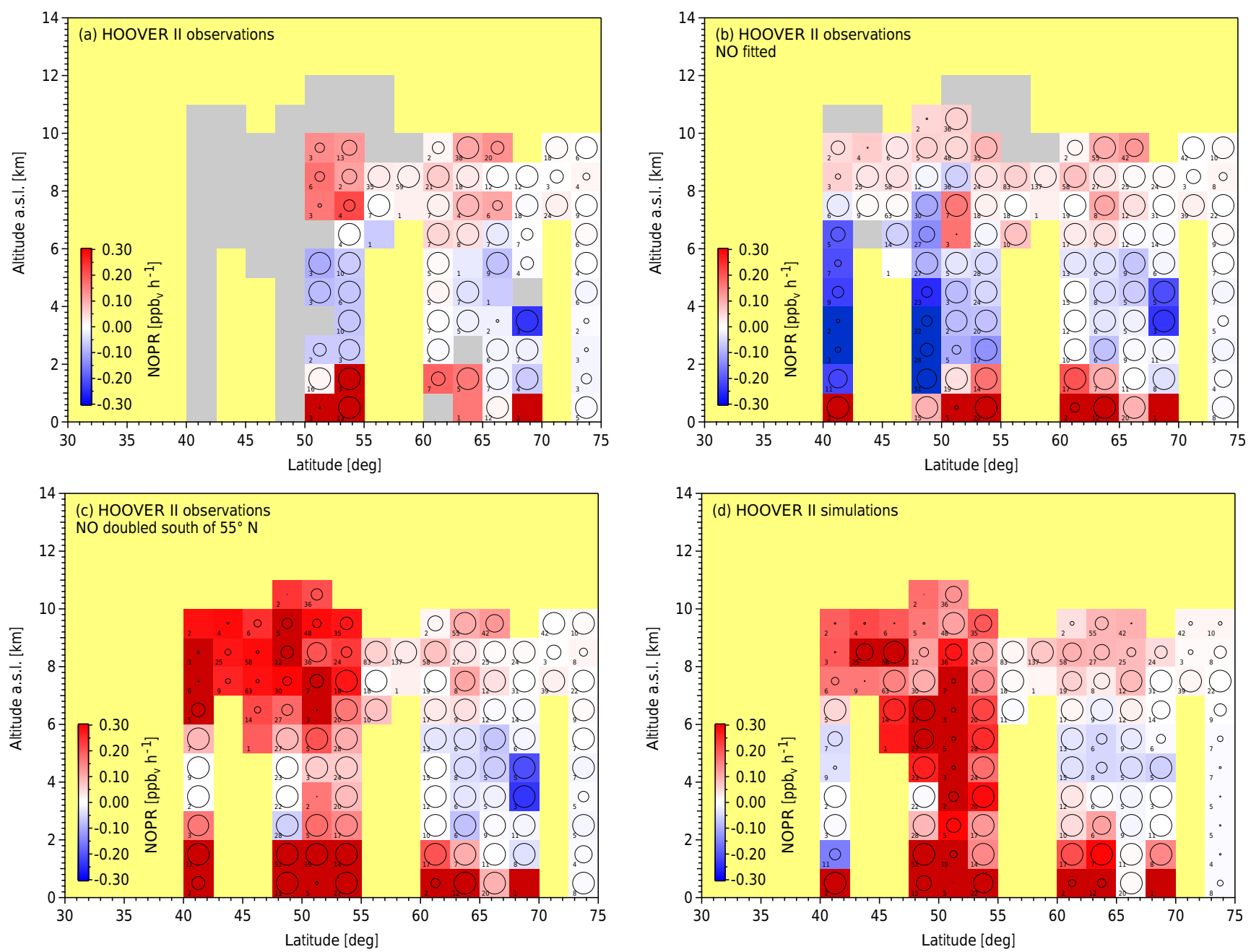

Figure 6. Net ozone production rates (NOPR) in $\mathrm{ppbv} \mathrm{h}^{-1}$ calculated from in situ data (a), fitted NO (b), double NO (c) and from MATCH simulations (d) for HOOVER II.

\subsection{The influence of deep convection on NOPR}

As outlined in Sect. 2.1 the analysis thus far has been restricted to "background conditions" by filtering data that have been affected by deep convection. Research flights to study the outflow of deep convection have been performed during both GABRIEL (Bozem et al., 2014) and HOOVER II (Regelin et al., 2013). Details about the convective systems, the flight tracks and trace gas measurements can be found in these articles.

During GABRIEL the outflow of a single convective cell at 9 to $11 \mathrm{~km}$ showed enhancements relative to background mixing ratios for $\mathrm{CO}, \mathrm{NO}, \mathrm{OH}$ and $\mathrm{HO}_{2}$ of 40, 130, 70 and $20 \%$, respectively. The $\mathrm{CO}$ increase with altitude suggests a strong contribution of boundary layer air. Transport of $\mathrm{HO}_{x}$ precursors from lower layers of the troposphere led to enhanced $\mathrm{OH}$ and $\mathrm{HO}_{2}$ concentrations in the outflow. The strong enhancement in NO is most likely due to additional
NO production from lightning. Ozone mixing ratios were also enhanced (38\%), which may contradict the expectation that transport of boundary layer air in convective systems should lead to a decrease in $\mathrm{O}_{3}$ mixing ratios in the outflow relative to the undisturbed middle and upper troposphere. A detailed discussion of the trace gas budgets, in particular for $\mathrm{O}_{3}$, can be found in Bozem et al. (2014). Figure 7a shows mean and median values for NOPR in the outflow at the $10.5 \mathrm{~km}$ bin relative to campaign background median and mean altitude profiles for non-convective air masses. The median value of $0.2 \mathrm{ppbv} \mathrm{h}^{-1}$ (mean: $0.27 \pm 0.13 \mathrm{ppbv} \mathrm{h}^{-1}$ ) is roughly a factor of 3 higher than the background value (median: $0.06 \mathrm{ppbvh}^{-1}$; mean: $0.06 \pm 0.04 \mathrm{ppbvh}^{-1}$ ). This is mainly due to the enhancement of $\mathrm{NO}$, in addition to the increase in peroxy radical concentrations.

In order to compare the GABRIEL results for NOPR with literature data for the tropics we estimate daily $\mathrm{O}_{3}$ production by multiplying the hourly value with a typical 

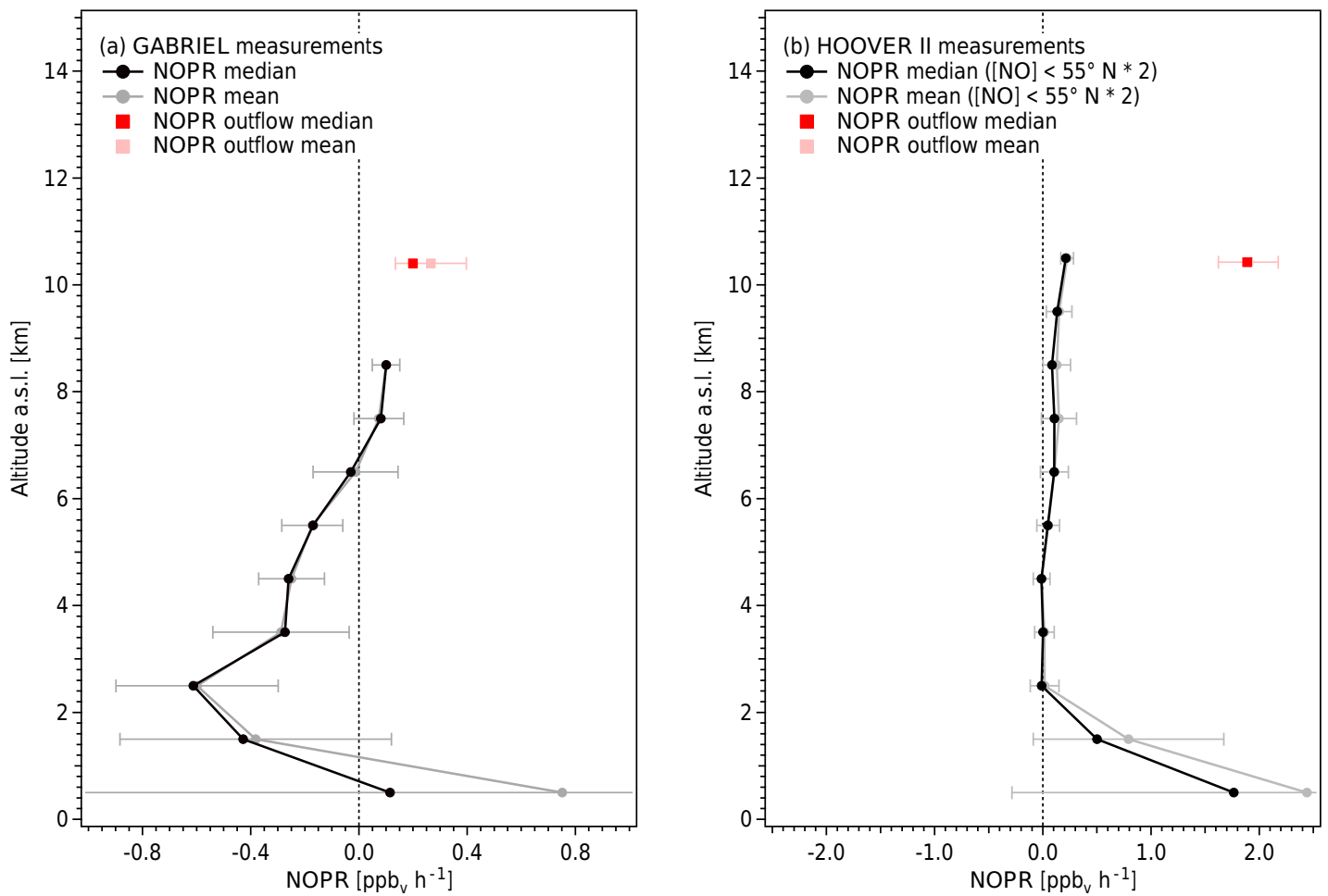

Figure 7. Net ozone production rates (NOPR) in $\mathrm{ppbvh}^{-1}$ (red squares) calculated from in situ data for convective events during GABRIEL (a) and HOOVER II (b) relative to campaign average profiles (black).

day length of $12 \mathrm{~h}$, yielding a value of $2.4 \mathrm{ppbv} \mathrm{d}^{-1}$ (range: $1.62-4.77 \mathrm{ppbv} \mathrm{d}^{-1}$ ). This is in good agreement with observations over the Brazilian rainforest during ABLE 2B (1.5$1.7 \mathrm{ppbv} \mathrm{d}^{-1}$ ) for conditions with an inflow from rural areas (Pickering et al., 1992a). For storms with an inflow characterized by urban environments generally higher values were deduced during ABLE 2B (16.5-17.2 ppbv d $^{-1}$ ) (Pickering et al., 1992a). Higher values were also observed for convective transport from biomass burning plumes during ABLE 2A over South America (7.4-8.5 ppbv d $^{-1}$ ) (Pickering et al., $1992 \mathrm{~b}$ ), while smaller values of the order of $1-1.5 \mathrm{ppbv} \mathrm{d}^{-1}$ have been observed over tropical oceans (Pickering et al., 1993; Schultz et al., 1999; Kita et al., 2003; Koike et al., 2007).

During HOOVER II an eastward moving mesoscale convective system developed over the southern part of Germany on 19 July 2007. During a research flight out of Baaden airport, in- and outflow of a strong convective cell were probed close to Dresden, the capital of the state of Saxony. The outflow at $10.5 \mathrm{~km}$ altitude showed enhancements relative to background mixing ratios for $\mathrm{CO}, \mathrm{NO}, \mathrm{OH}$ and $\mathrm{HO}_{2}$ by $85,600,350$ and $150 \%$, respectively, due to almost undiluted transport of boundary layer air to the upper troposphere and strong lightning activity. Ozone in the outflow was $20 \%$ lower than in background air (Bozem et al., 2017). As shown in Fig. $7 \mathrm{~b}$ this leads to a median NOPR of $1.89 \mathrm{ppbv}^{-1}$ (mean: $1.9 \pm 0.28 \mathrm{ppbvh}^{-1}$ ), a factor of 6 higher than the upper tropospheric background for HOOVER II (median: $0.29 \mathrm{ppbvh}^{-1}$; mean: $0.31 \pm 0.07 \mathrm{ppbvh}^{-1}$ ). The NOPR in the case study over Europe is an order of magnitude larger than over South America during GABRIEL. Median mixing ratios for NO during HOOVER and GABRIEL were 0.96 and $0.1 \mathrm{ppbv}$, respectively. Thus the difference in NOPR for the two case studies is mainly due to different NO concentrations. The median daily net ozone production for the HOOVER case is $22.67 \mathrm{ppbv} \mathrm{d}^{-1}$ (range: 19.47-26.11 $\mathrm{ppbv} \mathrm{d}^{-1}$ ) and about a factor of 2-4 larger than values reported in the literature for $\mathrm{NH}$ mid-latitudes, e.g. $\sim 15 \mathrm{ppbv} \mathrm{d}^{-1}$ during PRESTORM, Oklahoma (Pickering et al., 1990, 1992a), 10-13 ppbv d $^{-1}$ during STERAO-A over North America (DeCaria et al., 2005), up to 5 ppbv during EULINOX over Europe (Ott et al., 2007), and 5-7 ppbv d $\mathrm{d}^{-1}$ during DC3 over North America (Apel et al., 2015).

\section{Discussion and conclusions}

As mentioned in the Introduction, observation-based calculations of NOPR using airborne data are rare. The majority of these studies were made over the central and eastern Pacific (Cantrell et al., 2003a; Olson et al., 2001; Kondo et al., 2004; DiNunno et al., 2003; Davis et al., 2003; Schultz et al., 1999; Crawford et al., 1997a, b; Davis et al., 1996) or the Atlantic Ocean (Ren et al., 2008; Reeves et al., 2002; Ja- 
cob et al., 1996). Continental studies thus far are restricted to Australia (Ko et al., 2003), the east coast of North America (Ren et al., 2008), and high latitudes over North America (Olson et al., 2012; Cantrell et al., 2003b). This study is the first performed over the rainforest in South America (GABRIEL) and over continental Europe (HOOVER). It is also the first study that compares observation-based NOPR to a 3-D model simulation. Previous publications have used constrained box models, which are optimal tools to test the ozone production mechanism.

The net $\mathrm{O}_{3}$ tendencies derived from both in situ observations and 3-D-model simulations confirm earlier studies with net $\mathrm{O}_{3}$ formation (NOPR $>0$ ) taking place in the continental boundary layer and the upper troposphere (above approx. $7 \mathrm{~km}$ in the tropics and mid-latitudes), and net $\mathrm{O}_{3}$ destruction $(\mathrm{NOPR}<0)$ in the marine boundary layer and the lower free troposphere (between 1 and $6 \mathrm{~km}$ altitude). The main reason that explains this distinction is shown to be the NO concentration. Both observations and model simulations indicate that the fate of ozone depends on the amount of NO relative to the threshold NO concentration, derived from Eq. (7). In our study, the observed NO concentrations are always close to $\mathrm{NO}_{\text {th }}$ (between 10 and several hundred percent). The NOPR values are therefore almost linearly dependent on $\mathrm{NO}$, being typical for $\mathrm{NO}_{x}$-limited $\mathrm{O}_{3}$ production regimes (Seinfeld and Pandis, 1998).

This strong NO dependency also affects the comparison between in situ observations and model simulations. Although NOPR values show similar tendencies, absolute values are often slightly different, with the modelled absolute NOPR values typically being smaller in magnitude than observed (both for production and destruction regimes). This is partly due to differences in measured and simulated NO concentrations, as has been discussed for HOOVER II. An additional factor influencing the comparison is the calculated threshold NO value, which often differs for the observations and model simulations. This indicates that the reasons for the model-observation differences are complex and depend on more than one parameter.

Absolute values for NOPR are comparable to earlier observations. During INTEX-A, which was performed over the east coast of North America and the western Atlantic Ocean, mean NOPR values of $8.4,-0.8$ and $11.4 \mathrm{ppbv} \mathrm{d}^{-1}$ were observed for the boundary layer (BL), the middle troposphere (MT) and the upper troposphere (UT), respectively (Ren et al., 2008). Observed daily means of NOPR during HOOVER I (autumn season) are $\sim 2 \mathrm{ppbvd}^{-1}$ (BL), zero $(\mathrm{MT})$ and $\sim 1 \mathrm{ppbv} \mathrm{d}^{-1}(\mathrm{UT})$ increasing to $\sim 4 \mathrm{ppbv} \mathrm{d}^{-1}$ (BL), $-1 \mathrm{ppbv} \mathrm{d}^{-1}$ (MT) and $\sim 1 \mathrm{ppbv} \mathrm{d}^{-1}$ (UT) during the summer measurements (HOOVER II). These values are close to observation-based estimates by Olson et al. (2012) over North America during summer 2008 as part of the ARCTAS campaign (BL: 2 ppbv d ${ }^{-1}$; MT: -1 ppbvd $^{-1}$; UT: $1 \mathrm{ppbv} \mathrm{d}^{-1}$ ). Since no data have been reported previously for the troposphere over the tropical rainforest, absolute NOPR values for GABRIEL cannot be compared.

One remarkable feature is the shift to positive NOPR values above approx. $7 \mathrm{~km}$ altitude that is found in both observations and simulations. This shift occurs, although $\mathrm{NO}_{\text {th }}$ shows a tendency to increase at the highest altitudes. In previous publications $\mathrm{NO}_{\text {th }}$ has been designated as either $\mathrm{NO}_{\text {critical }}$ (e.g. Cantrell et al., 2003a) or as NO compensation point ( $\mathrm{NO}_{\text {comp }}$ ) (Reeves et al., 2002). Cantrell et al. (2003a) point out that for a number of campaigns critical NO levels generally encompass a "triangular" envelope bounded by about 5 pptv and a line between 25 pptv at the surface and 5 pptv at $12 \mathrm{~km}$ altitude (Fig. 10e in Cantrell et al., 2003a). Both observation-derived and model-calculated $\mathrm{NO}_{\text {th }}$ values from this study fit into the triangle defined by Cantrell et al. (2003a), but they differ at the highest altitudes. While the campaigns listed by Cantrell et al. (2003a) show either constant values throughout the troposphere or decreasing values with altitude, we find an increase in $\mathrm{NO}_{\text {th }}$ at the highest flight levels during both HOOVER campaigns. According to Eq. (6) this increase in $\mathrm{NO}_{\text {th }}$ can be either due to an increase in the $\mathrm{O}_{3}$ sinks (photolysis and subsequent reaction with $\mathrm{H}_{2} \mathrm{O}$ or reaction with $\mathrm{OH}$ or $\mathrm{HO}_{2}$ ), which are directly and positively correlated to the ozone concentration, or a decrease in the $\mathrm{O}_{3}$ source (concentrations of $\mathrm{HO}_{2}$ and $\mathrm{CH}_{3} \mathrm{O}_{2}$ ). Due to the pressure decrease by a factor of 4 from the surface to $10 \mathrm{~km}$ altitude the concentrations of the radical precursors $\left(\mathrm{CO}, \mathrm{CH}_{4}\right)$ also decrease by a factor of 4 , which strongly reduces the concentrations of $\mathrm{HO}_{2}$ and $\mathrm{CH}_{3} \mathrm{O}_{2}$ radicals and thus the denominator of Eq. (6). Ozone exhibits strongly increasing mixing ratios with altitude that compensate for the pressure reduction effect, leading to an almost constant concentration throughout the troposphere. Overall this leads to a rather invariable $\mathrm{O}_{3}$ loss rate throughout the troposphere even at the strongly decreasing $\mathrm{H}_{2} \mathrm{O}$ concentrations in the upper troposphere. Most likely the observed increase in $\mathrm{NO}_{\text {th }}$ in the tropopause region during the HOOVER campaigns is due to a combination of strongly increasing ozone concentrations and decreasing radical $\left(\mathrm{HO}_{2}, \mathrm{CH}_{3} \mathrm{O}_{2}\right)$ concentrations. Reeves et al. (2002) report a similar increase in $\mathrm{NO}_{\text {comp }}$ observed in the middle troposphere over the Atlantic (Fig. 5b

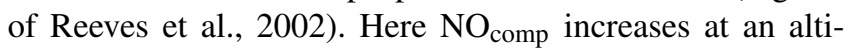
tude of $3 \mathrm{~km}$ due to a strong increase in ozone. To obtain net $\mathrm{O}_{3}$ production above $7 \mathrm{~km}$ altitude, a strong increase in NO concentrations with altitude is required. This NO increase with altitude is partly due to a shift in the partitioning in $\mathrm{NO}_{x}$, yielding higher $\mathrm{NO}$ concentrations at high altitude due to the temperature dependency of the $\mathrm{NO}+\mathrm{O}_{3}$ reaction, whose rate constant decreases with decreasing temperature (Ehhalt et al., 1992; Ziereis et al., 2000). Additional sources of NO associated with convection, lightning and downward transport from the stratosphere further enhance NO at high altitudes (Schumann and Huntrieser, 2007), resulting in the positive NOPR values above $7 \mathrm{~km}$ altitude obtained for all three campaigns. The case studies of enhanced NOPR val- 
ues associated with convection and lightning-produced $\mathrm{NO}_{x}$ in Sect. 3.5 thus indicate that the general increase in NOPR above $7 \mathrm{~km}$ altitude is most likely due to the integral effect of convection on the upper troposphere.

Data availability. Readers who are interested in the data should contact the authors: Heiko Bozem (bozemh@uni-mainz.de) or Horst Fischer (horst.fischer@mpic.de).

Competing interests. The authors declare that they have no conflict of interest.

Acknowledgements. The authors would like to thank Uwe Parchatka, Rainer Königstedt, and Corinne Schiller for their help with the measurements. We would also like to acknowledge the support from the GABRIEL and HOOVER teams, envisvcope $\mathrm{GmbH}$ (Frankfurt), and GFD (Gesellschaft für Zielflugdarstellung, Hohn).

The article processing charges for this open-access publication were covered by the Max Planck Society.

Edited by: Dwayne Heard

Reviewed by: two anonymous referees

\section{References}

Apel, E. C., Hornbrook, R. S., Hills, A. J., Blake, N. J., Barth, M. C., Weinheimer, A., Cantrell, C., Rutledge, S. A., Basarab, B., Crawford, J., Diskin, G., Homeyer, C. R., Campos, T., Flocke, F., Fried, A., Blake, D. R., Brune, W., Pollack, I., Peischl, J., Ryerson, T., Wennberg, P. O., Crounse, J. D., Wisthaler, A., Mikoviny, T., Huey, G., Heikes, B., O’Sullivan, D., and Riemer, D. D.: Upper tropospheric ozone production from lightning $\mathrm{NO}_{x}$-impacted convection: Smoke ingestion case study from the DC3 campaign, J. Geophys. Res.-Atmos., 120, 2505-2523, https://doi.org/10.1002/2014JD022121, 2015.

Bozem, H., Fischer, H., Gurk, C., Schiller, C. L., Parchatka, U., Koenigstedt, R., Stickler, A., Martinez, M., Harder, H., Kubistin, D., Williams, J., Eerdekens, G., and Lelieveld, J.: Influence of corona discharge on the ozone budget in the tropical free troposphere: a case study of deep convection during GABRIEL, Atmos. Chem. Phys., 14, 8917-8931, https://doi.org/10.5194/acp14-8917-2014, 2014.

Bozem, H., Pozzer, A., Harder, H., Martinez, M., Williams, J., Lelieveld, J., and Fischer, H.: The influence of deep convection on $\mathrm{HCHO}$ and $\mathrm{H}_{2} \mathrm{O}_{2}$ in the upper troposphere over Europe, Atmos. Chem. Phys. Discuss., https://doi.org/10.5194/acp-2017154, in review, 2017.

Brunner, D., Staehelin, J., Jeker, D., Wernli, H., and Schumann, U.: Nitrogen oxides and ozone in the tropopause region of the northern hemisphere: Measurements from commercial aircraft in 1995/1996 and 1997, J. Geophys. Res., 106, 27673-27699, https://doi.org/10.1029/2001JD900239, 2001.
Cantrell, C. A., Shetter, R. E., Gilpin, T. M., and Calvert, J. G.: Peroxy radicals measured during Mauna Loa Observatory Photochemistry Experiment 2: The data and first analysis, J. Geophys. Res., 101, 14643-14652, https://doi.org/10.1029/95JD01698, 1996.

Cantrell, C. A., Edwards, G. D., Stephens, S., et al.: Peroxy radical behaviour during the Transport and Chemical Evolution over the Pacific (TRACE-P) campaign as measured aboard the NASA P-3B aircraft, J. Geophys. Res., 108, 8797, https://doi.org/10.1029/2003JD003674, 2003a.

Cantrell, C. A., Mauldin, L., Zondlo, M., et al.: Steady state free radical budgets and ozone photochemistry during TOPSE, J. Geophys. Res., 108, 8361, https://doi.org/10.1029/2002JD002198, 2003b.

Cazorla, M. and Brune, W. H.: Measurement of Ozone Production Sensor, Atmos. Meas. Tech., 3, 545-555, https://doi.org/10.5194/amt-3-545-2010, 2010.

Chameides, W. and Walker, J. C. G.: A photochemical theory of tropospheric ozone, J. Geophys. Res., 78, 8751-8760, https://doi.org/10.1029/JC078i036p08751, 1973.

Colomb, A., Williams, J., Crowley, J., Gros, V., Hofmann, R., Salisbury, G., Kluepfel, T., Kormann, R., Stickler, A., Forster, C., and Lelieveld, J.: Airborne measurements of trace organic species in the upper troposphere over Europe: the impact of deep convection, Environ. Chem. 3, 244-259, https://doi.org/10.1071/EN06020, 2006.

Crawford, J. H., Davis, D. D., Chen, G., Bradshaw, J., Sandholm, S., Kondo, Y., Merrill, J., Liu, S., Browell, E., Gregory, G., Anderson, B., Sachse, G., Barrick, J., Blake, D., Talbot, R., and Pueschel R.: Implications of large scale shifts in tropospheric $\mathrm{NO}_{x}$ levels in the remote tropical Pacific, J. Geophys. Res., 102, 28447-28468, https://doi.org/10.1029/97JD00011, 1997a.

Crawford, J., Davis, D., Chen, G., Bradshaw, J., Sandholm, S., Kondo, Y., Liu, S., Browell, E., Gregory, G., Anderson, B., Sachse, G., Collins, J., Barrick, J., Blake, D., Talbot, R., and Singh, H.: An assessment of ozone photochemistry in the extratropical western North Pacific: Impact of continental outflow during the late winter/early spring, J. Geophys. Res., 102, 2846928487, https://doi.org/10.1029/97JD02600, 1997b.

Crutzen, P. J.: Photochemical reactions initiated by and influencing ozone in unpolluted tropospheric air, Tellus, 26, 47-57, https://doi.org/10.1111/j.2153-3490.1974.tb01951.x, 1973.

Davis, D. D., Crawford, J., Chen, G., Chameides, W., Liu, S., Bradshaw, J., Sandholm, S., Sachse, G., Gregory, G., Anderson, B., Barrick, J., Bachmeier, A., Collins, J., Browell, E., Blake, D., Rowland, S., Kondo, Y., Singh, H., Talbot, R., Heikes, B., Merrill, J., Rodriguez, J., and Newell, R. E.: Assessment of ozone photochemistry in the western North Pacific as inferred from PEM-West A observations during the fall 1991, J. Geophys. Res., 101, 2111-2134, https://doi.org/10.1029/95JD02755, 1996.

Davis, D. D., Chen, G., Crawford, J. H., Liu, S., Tan, D., Sandholm, S. T., Jing, P., Cunnold, D. M., DiNunno, B., Browell, E. V., Grant, W. B., Fenn, M. A., Anderson, B. E., Barrick, J. D., Sachse, G. W., Vay, S. A., Hudgins, C. H., Avery, M. A., Lefer, B., Shetter, R. E., Heikes, B. G., Blake, D. R., Blake, N., Kondo, Y., and Oltmans, S.: An assessment of western North Pacific ozone photochemistry based on springtime observations from NASA's PEM-West B (1994) and 
TRACE-P (2001) field studies, J. Geophys. Res., 108, 8829, https://doi.org/10.1029/2002JD003232, 2003.

DeCaria, A. J., Pickering, K. E., Stenchikov, G. L., and Ott, L. E.: Lightning-generated $\mathrm{NO}_{x}$ and its impact on tropospheric ozone production: A three-dimensional modeling study of a Stratosphere-Troposphere Experiment: Radiation, Aerosols and Ozone (STERAO-A) thunderstorm, J. Geophys. Res., 110, D14303, https://doi.org/10.1029/2004JD005556, 2005

DiNunno, B., Davis, D., Chen, G., Crawford, J., Olson, J., and Liu, S.: An assessment of ozone photochemistry in the central/eastern North Pacific as determined from multiyear airborne field studies, J. Geophys. Res., 108, 8237, https://doi.org/10.1029/2001JD001468, 2003.

Ehhalt, D. H., Rohrer, F., and Wahner, A.: Sources and distribution of $\mathrm{NO}_{x}$ in the upper troposphere at northern mid-latitudes, J. Geophys. Res., 97, 3725-3738, https://doi.org/10.1029/91JD03081, 1992.

Fischer, H., Kormann, R., Klüpfel, T., Gurk, Ch., Königstedt, R., Parchatka, U., Mühle, J., Rhee, T. S., Brenninkmeijer, C. A. M., Bonasoni, P., and Stohl, A.: Ozone production and trace gas correlations during the June 2000 MINATROC intensive measurement campaign at Mt. Cimone, Atmos. Chem. Phys., 3, 725-738, https://doi.org/10.5194/acp-3-725-2003, 2003.

Fischer, H., Lawrence, M., Gurk, Ch., Hoor, P., Lelieveld, J., Hegglin, M. I., Brunner, D., and Schiller, C.: Model simulations and aircraft measurements of vertical, seasonal and latitudinal $\mathrm{O}_{3}$ and CO distributions over Europe, Atmos. Chem. Phys., 6, 339-348, https://doi.org/10.5194/acp-6-339-2006, 2006.

Gurk, Ch., Fischer, H., Hoor, P., Lawrence, M. G., Lelieveld, J., and Wernli, H.: Airborne in-situ measurements of vertical, seasonal and latitudinal distributions of carbon dioxide over Europe, Atmos. Chem. Phys., 8, 6395-6403, https://doi.org/10.5194/acp8-6395-2008, 2008.

Haagen-Smith, A. J. and Fox, M. M.: Ozone Formation in Photochemical Oxidation of Organic Substances, Ind. Eng. Chem., 48, 1484-1487, https://doi.org/10.1021/ie51400a033, 1956.

Hosaynali Beygi, Z., Fischer, H., Harder, H. D., Martinez, M., Sander, R., Williams, J., Brookes, D. M., Monks, P. S., and Lelieveld, J.: Oxidation photochemistry in the Southern Atlantic boundary layer: unexpected deviations of photochemical steady state, Atmos. Chem. Phys., 11, 8497-8513, https://doi.org/10.5194/acp-11-8497-2011, 2011.

Jacob, D. J., Heikes, E. G., Fan, S.-M., Logan, J. A., Mauzerall, D. L., Bradshaw, J. D., Singh, H. B., Gregory, G. L., Talbot, R. W., Blake, D. R., and Sachse, G. W.: Origin of ozone and $\mathrm{NO}_{x}$ in the tropical troposphere: A photochemical analysis of aircraft observations over the South Atlantic basin, J. Geophys. Res., 101, 24235-24250, https://doi.org/10.1029/96JD00336, 1996.

Junge, C. E.: Air chemistry and radioactivity, International Geophysics Series, Academic Press, New York, USA, https://doi.org/10.1002/qj.49709038422, 1963.

Kanaya, Y., Matsumoto, J., and Akimoto, H.: Photochemical ozone production at a subtropical island of Okinawa, Japan: Implications from simultaneous observations of $\mathrm{HO}_{2}$ radical and $\mathrm{NO}_{x}$, J. Geophys. Res., 107, 4368, https://doi.org/10.1029/2001JD000858, 2002.

Kita, K., Kawakami, S., Miyazaki, Y., Higashi, Y., Kondo, Y., Nishi, N., Koike, M., Blake, D. R., Machida, T., Sano, T., Hu, W., Ko, M., and Ogawa, T.: Photochemical production of ozone in the upper troposphere in association with cumulus convection over Indonesia, J. Geophys. Res., 108, 8400, https://doi.org/10.1029/2001JD000844, 2003.

Kleinman, L. I.: Ozone process insights from field experiments part II: Observation-based analysis for ozone production, Atmos. Environm., 34, 2023-2033, https://doi.org/10.1016/S13522310(99)00457-4, 2000.

Kleinman, L. I., Daum, P. H., Lee, Y.-N., Nunnermacker, L. J., Sprinston, S. R., Weinstein-Lloyd, J., and Rudolph, J.: A comparative study of ozone production from five U.S. metropolitan areas, J. Geophys. Res., 110, D02301, https://doi.org/10.1029/2004JD005096, 2005.

Klippel, T., Fischer, H., Bozem, H., Lawrence, M. G., Butler, T., Jöckel, P., Tost, H., Martinez, M., Harder, H., Regelin, E., Sander, R., Schiller, C. L., Stickler, A., and Lelieveld, J.: Distribution of hydrogen peroxide and formaldehyde over Central Europe during the HOOVER project, Atmos. Chem. Phys., 11, 4391-4410, https://doi.org/10.5194/acp-11-4391-2011, 2011.

Klonecki, A. and Levy, H.: Tropospheric chemical ozone tendencies in $\mathrm{CO}-\mathrm{CH}_{4}-\mathrm{NO}_{y}-\mathrm{H}_{2} \mathrm{O}$ system: Their sensitivity to variations in environmental parameters and their application to a global chemistry transport model study, J. Geophys. Res., 102, 21221-21237, https://doi.org/10.1029/97JD01805, 1997.

Ko, M., Hu, W., Rodriguez, J.M., Kondo, Y., Koike, M., Kita, K., Kawakami, S., Blake, D., Liu, S., and Ogawa, T.: Photochemical ozone budget during the BIBLE A and B campaigns, J. Geophys. Res., 108, 8404, https://doi.org/10.1029/2001JD000800, 2003.

Koike, M., Kondo, Y., Kita, K., Takegawa, N., Nishi, N., Kashihara, T., Kawakami, S., Kudoh, S., Blake, D., Shirai, T., Liley, B., Ko, M., Miyazaki, Y., Kawasaki, Z., and Ogawa, T.: Measurements of reactive nitrogen produced by tropical thunderstorms during BIBLE-C, J. Geophys. Res., 112, D18304, https://doi.org/10.1029/2006JD008193, 2007.

Kondo, Y., Nakamura, K., Chen, G., Takegawa, N., Koike, M., Miyazaki, Y., Kita, K., Crawford, J., Ko, M., Blake, D. R., Kawakami, S., Shirai, T., Liley, B., Wang, Y., and Ogawa, T.: Photochemistry of ozone over the western Pacific from winter to spring, J. Geophys. Res., 109, D23S02, https://doi.org/10.1029/2004JD004871, 2004.

Kubistin, D., Harder, H., Martinez, M., Rudolf, M., Sander, R., Bozem, H., Eerdekens, G., Fischer, H., Gurk, C., Klüpfel, T., Königstedt, R., Parchatka, U., Schiller, C. L., Stickler, A., Taraborrelli, D., Williams, J., and Lelieveld, J.: Hydroxyl radicals in the tropical troposphere over the Suriname rainforest: comparison of measurements with the box model MECCA, Atmos. Chem. Phys., 10, 9705-9728, https://doi.org/10.5194/acp10-9705-2010, 2010.

Kuhn, U., Ganzeveld, L., Thielmann, A., Dindorf, T., Schebeske, G., Welling, M., Sciare, J., Roberts, G., Meixner, F. X., Kesselmeier, J., Lelieveld, J., Kolle, O., Ciccioli, P., Lloyd, J., Trentmann, J., Artaxo, P., and Andreae, M. O.: Impact of Manaus City on the Amazon Green Ocean atmosphere: ozone production, precursor sensitivity and aerosol load, Atmos. Chem. Phys., 10, 9251-9282, https://doi.org/10.5194/acp-10-9251-2010, 2010.

Lawrence, M. G., Rasch, P. J., von Kuhlmann, R., Williams, J., Fischer, H., de Reus, M., Lelieveld, J., Crutzen, P. J., Schultz, M., Stier, P., Huntrieser, H., Heland, J., Stohl, A., Forster, C., Elbern, H., Jakobs, H., and Dickerson, R. R.: Global chemical weather forecasts for field campaign planning: predic- 
tions and observations of large-scale features during MINOS, CONTRACE, and INDOEX, Atmos. Chem. Phys., 3, 267-289, https://doi.org/10.5194/acp-3-267-2003, 2003.

Leighton, P. A.: Photochemistry of air pollution, Academic Press, New York, USA, 1961.

Lelieveld, J. and Dentener, F. J.: What controls tropospheric ozone?, J. Geophys. Res., 105, 3531-3551, https://doi.org/10.1029/1999JD901011, 2000.

Lelieveld, J., Butler, T. M., Crowley, J. N., Dillon, T. J., Fischer, H., Ganzeveld, L., Harder, H., Lawrence, M. G., Martinez, M., Taraborrelli, D., and Williams, J.: Atmospheric oxidation capacity sustained by a tropical forest, Nature, 452, 737-740, https://doi.org/10.1038/nature06870, 2008.

Levy II, H.: Normal atmosphere: Large radical and formaldehyde concentrations predicted, Science, 173, 141-143, https://doi.org/10.1126/science.173.3992.141, 1971.

Liu, Z., Wang, Y., Gu, D., Zhao, C., Huey, L. G., Stickel, R., Liao, J., Shao, M., Zhu, T., Zeng, L., Amoroso, A., Costabile, F., Chang, C.-C., and Liu, S.-C.: Summertime photochemistry during CAREBeijing-2007: $\mathrm{RO}_{x}$ budgets and $\mathrm{O}_{3}$ formation, Atmos. Chem. Phys., 12, 7737-7752, https://doi.org/10.5194/acp12-7737-2012, 2012.

Madronich, S. and Flocke, S.: The role of solar radiation in atmospheric chemistry, in: The Handbook of Environmental Chemistry, Vol. 2, Part L, Environmental Photochemistry, edited by: Boule, P., Springer, Berlin, Germany, 1999.

Martinez, M., Harder, H., Kubistin, D., Rudolf, M., Bozem, H., Eerdekens, G., Fischer, H., Klüpfel, T., Gurk, C., Königstedt, R., Parchatka, U., Schiller, C. L., Stickler, A., Williams, J., and Lelieveld, J.: Hydroxyl radicals in the tropical troposphere over the Suriname rainforest: airborne measurements, Atmos. Chem. Phys., 10, 3759-3773, https://doi.org/10.5194/acp10-3759-2010, 2010.

Olivier, J. G. J., Peters, J. A. H. W., Bakker, J., Berdowski, J. J. M., Visschedijk, A. J. H., and Bloos, J. P. J.: Applications of EDGAR: Emission data base for atmospheric research, Rep. 410.200.051.RIVM, RIVM, Bilthoven, the Netherlands, 2002.

Olson, J. R., Crawford, J. H., Davis, D. D., Chen, G., Avery, M. A., Barrick, J. D. W., Sachse, G. W., Vay, S. A., Sandholm, S. T., Tan, D., Brune, W. H., Faloona, I. C., Heikes, B. G., Shetter, R. E., Lefer, B. L., Singh, H. B., Talbot, R. W., and Blake D. R.: Seasonal differences in the photochemistry of the South Pacific: A comparison of observations and model results from PEM-Tropics A and B, J. Geophys. Res., 106, 32749-32766, https://doi.org/10.1029/2001JD900077, 2001.

Olson, J. R., Crawford, J. H., Brune, W., Mao, J., Ren, X., Fried, A., Anderson, B., Apel, E., Beaver, M., Blake, D., Chen, G., Crounse, J., Dibb, J., Diskin, G., Hall, S. R., Huey, L. G., Knapp, D., Richter, D., Riemer, D., Clair, J. St., Ullmann, K., Walega, J., Weibring, P., Weinheimer, A., Wennberg, P., and Wisthaler, A.: An analysis of fast photochemistry over high northern latitudes during spring and summer using in-situ observations from ARCTAS and TOPSE, Atmos. Chem. Phys., 12, 6799-6825, https://doi.org/10.5194/acp-12-6799-2012, 2012.

Ott, L. E., Pickering, K. E., Stenchikov, G. L., Huntrieser, H., and Schumann, U.: Effects of lightning $\mathrm{NO}_{x}$ production during the 21 July European Lightning Nitrogen Oxides Project storm studied with a three-dimensional cloud- scale chemical transport model, J. Geophys. Res., 112, D05307, https://doi.org/10.1029/2006JD007365, 2007.

Penkett, S. A., Monks, P. S., Carpenter, L. J., Clemitshaw, K. C., Ayers, G. P., Gillett, R. W., Galbally, I. E., and Meyer, C. P.: Relationships between ozone photolysis rates and peroxy radical concentrations in clean marine air over the Southern Ocean, J. Geophys. Res., 102, 12805-12817, https://doi.org/10.1029/97JD00765, 1997.

Pickering, K. E., Thompson, A. M., Dickerson, R. R., Luke, W. T., McNamara, D. P., Greenberg, J. P., and Zimmerman, P. R.: Model calculations of tropospheric ozone production potential following observed convective events, J. Geophys. Res., 95, 1404914062, https://doi.org/10.1029/JD095iD09p14049, 1990.

Pickering, K. E., Thompson, A. M., Scala, J. R., Tao, W.K., Dickerson, R. R., and Simpson, J.: Free tropospheric ozone production following entrainment of urban plumes into deep convection, J. Geophys. Res., 97, 17985-18000, https://doi.org/10.1029/92JD01716, 1992a.

Pickering, K. E., Thompson, A. M., Scala, J. R., Tao, W. K., and Simpson, J.: Ozone production potential following convective redistribution of biomass burning emissions, J. Atmos. Chem., 14, 297-313, https://doi.org/10.1007/BF00115241, 1992b.

Pickering, K. E., Thompson, A. M., Tao, W.-K., and Kucsera, T. L.: Upper tropospheric ozone production following mesoscale convection during STEP/EMEX, J. Geophys. Res., 98, 8737-8749, https://doi.org/10.1029/93JD00875, 1993.

Pusede, S. E., Steiner, A. L., and Cohen, R. C.: Temperature and recent trends in the chemistry of continental surface ozone, Chem. Rev., 115, 3898-3918, https://doi.org/10.1021/cr5006815, 2015.

Reeves, C. E., Penkett, S., Bauguitte, S., Law, K. S. Evans, M. J., Bandy, B. J., Monks, P. S., Edwards, G. D., Phillips, G., Barjat, H., Kent, J., Dewey, K., Schmitgen, S., and Kley, D.: Potential for photochemical ozone formation in the troposphere over the North Atlantic as derived from aircraft observations during ASCOE, J. Geophys. Res., 107, 4707, https://doi.org/10.1029/2002JD002415, 2002.

Regelin, E., Harder, H., Martinez, M., Kubistin, D., Tatum Ernest, C., Bozem, H., Klippel, T., Hosaynali-Beygi, Z., Fischer, H., Sander, R., Jöckel, P., Königstedt, R., and Lelieveld, $\mathrm{J} .: \mathrm{HO}_{x}$ measurements in the summertime upper troposphere over Europe: a comparison of observations to a box model and a 3-D model, Atmos. Chem. Phys., 13, 10703-10720, https://doi.org/10.5194/acp-13-10703-2013, 2013.

Ren, X., Olson, J. R., Crawford, J. H., Brune, W. H., Mao, J., Long, R. B., Chen, Z., Chen, G., Avery, M. A., Sachse, G. W., Barrick, J. D., Diskin, G. S., Huey, L. G., Fried, A., Cohen, R. C., Heikes, B., Wennberg, P. O., Singh, H. B., Blake, D. R., and Shetter, R. E.: $\mathrm{HO}_{x}$ chemistry during INTEX-A 2004: Observation, model calculation, and comparison with previous studies, J. Geophys. Res., 113, D05310, https://doi.org/10.1029/2007JD009166, 2008.

Ren, X., van Duin, D., Cazorla, M., Chen, S., Mao, J., Zhang, L., Brune, W. H., Flynn, J. H., Grossberg, N., Lefer, B. L., Rappenglück, B., Wong, K. W., Tsai, C., Stutz, J., Dibb, J. E., Jobson, B. T., Luke, W. T., and Kelley, P.: Atmospheric oxidation chemistry and ozone production: Results from SHARP 2009 in Houston, Texas, J. Geophys. Res.-Atmos., 118, 5770-5780, https://doi.org/10.1002/jgrd.50342, 2013. 
Roelofs, G.-J. and Lelieveld, J.: Model study of the influence of cross-tropopause $\mathrm{O}_{3}$ transports on tropospheric $\mathrm{O}_{3}$ levels, Tellus B, 49, 38-55, https://doi.org/10.1034/j.1600-0889.49.issue1.3.x, 1997.

Schiller, C. I., Bozem, H., Gurk, C., Parchatka, U., Königstedt, R., Harris, G. W., Lelieveld, J., and Fischer, H.: Applications of quantum cascade lasers for ensitive trace gas measurements of $\mathrm{CO}, \mathrm{CH}_{4}, \mathrm{~N}_{2} \mathrm{O}$, and HCHO, Appl. Phys., B92, 419-430, https://doi.org/10.1007/s00340-008-3125-0, 2008.

Schultz, M. G., Jacob, D. J., Wang, Y., Logan, J. A., Atlas, E. L., Blake, D. R., Blake, N. J., Bradshaw, J. D., Browell, E. V., Fenn, M. A., Flocke, F., Gregory, G. L., Heikes, B. G., Sachse, G. W., Sandholm, S. T., Shetter, R. E., Singh, H. B., and Talbot, R. W.: On the origin of tropospheric ozone and $\mathrm{NO}_{x}$ over the tropical South Pacific, J. Geophys. Res., 104, 5829-5843, https://doi.org/10.1029/98JD02309, 1999.

Schumann, U. and Huntrieser, H.: The global lightning-induced nitrogen oxides source, Atmos. Chem. Phys., 7, 3823-3907, https://doi.org/10.5194/acp-7-3823-2007, 2007.

Seinfeld, J. H. and Pandis, S. N.: Atmospheric Chemistry and Physics, John Wiley \& Sons, New York, USA, 299-302, 1998.

Shetter, R. E., Cinquini, L., Lefer, B. L., Hall, S. R., and Madronich, S.: Comparison of airborne measured and calculated spectral actinic flux and derived photolysis frequencies during the PEM tropics B mission, J. Geophys. Res., 108, 8234, https://doi.org/10.1029/2001JD001320, 2003.

Sommariva, R., Brown, S. S., Roberts, J. M., Brookes, D. M., Parker, A. E., Monks, P. S., Bates, T. S., Bon, D., de Gouw, J. A., Frost, G. J., Gilman, J. B., Goldan, P. D., Herndon, S. C., Kuster, W. C., Lerner, B. M., Osthoff, H. D., Tucker, S. C., Warneke, C., Williams, E. J., and Zahniser, M. S.: Ozone production in remote oceanic and industrial areas derived from ship based measurements of peroxy radicals during TexAQS 2006, Atmos. Chem. Phys., 11, 2471-2485, https://doi.org/10.5194/acp11-2471-2011, 2011.

Stevenson, D. S., Dentener, F. J., Schultz, M. G., et al.: Multimodel ensemble simulations of present-day and nearfuture tropospheric ozone, J. Geophys. Res., 111, D08301, https://doi.org/10.1029/2005JD006338, 2006.
Stickler, A., Fischer, H., Williams, J., de Reus, M., Sander, R., Lawrence, M. G., Crowley, J. N., and Lelieveld, J.: Influence of summertime deep convection on formaldehyde in the middle and upper troposphere over Europe, J. Geophys. Res., 111, D14308, https://doi.org/10.1029/2005JD007001, 2006.

Taraborrelli, D., Lawrence, M. G., Crowley, J. N., Dillon, T. J., Gromov, S., Groß, C. B. M., Vereecken, L., and Lelieveld, J.: Hydroxyl radical buffered by isoprene oxidation over tropical forests, Nat. Geosci., 5, 190-193, https://doi.org/10.1038/ngeo1405, 2012.

von Kuhlmann, R., Lawrence, M. G., Crutzen, P. J., and Rasch, P. J.: A model for studies of tropospheric ozone and nonmethane hydrocarbons: Model evaluation of ozone-related species, J. Geophys. Res., 108, 4729, https://doi.org/10.1029/2002JD003348, 2003.

Wild, O.: Modelling the global tropospheric ozone budget: exploring the variability in current models, Atmos. Chem. Phys., 7, 2643-2660, https://doi.org/10.5194/acp-7-2643-2007, 2007.

Wu, S., Mickley, L. J., Jacob, D. J., Logan, J. A., Yantosca, R. M., and Rind, D.: Why are there large differences between models in global budgets of tropospheric ozone?, J. Geophys. Res., 112, D05302, https://doi.org/10.1029/2006JD007801, 2007.

Zanis, P., Monks, P. S., Schuepbach, E., Carpenter, L. J., Green, T. J., Mills, G. P., Bauguitte, S., and Penkett, S. A.: In situ ozone production under free tropospheric conditions during FREETEX '98 in the Swiss Alps, J. Geophys. Res., 105, 24223-24234, https://doi.org/10.1029/2000JD900229, 2000.

Ziereis, H., Schlager, H., Schulte, P., vanVelthoven, P. F. J., and Slemr, F.: Distributions of $\mathrm{NO}, \mathrm{NO}_{x}$, and $\mathrm{NO}_{y}$ in the upper troposphere and lower stratosphere between $28^{\circ}$ and $61^{\circ} \mathrm{N}$ during POLINAT 2, J. Geophys. Res., 105, 3653-3664, https://doi.org/10.1029/1999JD900870, 2000. 